\title{
Historic global biomass burning emissions for CMIP6 (BB4CMIP) based on merging satellite observations with proxies and fire models (1750-2015)
}

\author{
Margreet J. E. van Marle ${ }^{1, a}$, Silvia Kloster ${ }^{2}$, Brian I. Magi ${ }^{3}$, Jennifer R. Marlon ${ }^{4}$, Anne-Laure Daniau ${ }^{5}$, \\ Robert D. Field ${ }^{6}$, Almut Arneth ${ }^{7}$, Matthew Forrest ${ }^{8}$, Stijn Hantson ${ }^{7}$, Natalie M. Kehrwald ${ }^{9}$, Wolfgang Knorr ${ }^{10}$, \\ Gitta Lasslop $^{2}$, Fang Li ${ }^{11}$, Stéphane Mangeon ${ }^{12}$, Chao Yue ${ }^{13}$, Johannes W. Kaiser ${ }^{14}$, and Guido R. van der Werf ${ }^{1}$ \\ ${ }^{1}$ Faculty of Earth and Life Sciences, Vrije Universiteit Amsterdam, Amsterdam, the Netherlands \\ ${ }^{2}$ Max Planck Institute for Meteorology, Bundesstraße 53, Hamburg, Germany \\ ${ }^{3}$ Department of Geography and Earth Sciences, University of North Carolina at Charlotte, Charlotte, NC, USA \\ ${ }^{4}$ School of Forestry and Environmental Studies, Yale University, New Haven, CT, USA \\ ${ }^{5}$ Environnements et Paléoenvironnements Océaniques et Continentaux, UMR EPOC 5805 CNRS, University of Bordeaux, \\ Pessac, France \\ ${ }^{6}$ NASA Goddard Institute for Space Studies, New York, NY, USA \\ ${ }^{7}$ Karlsruhe Institute of Technology, Institute of Meteorology and Climate research, Atmospheric Environmental Research, \\ Garmisch-Partenkirchen, Germany \\ ${ }^{8}$ Senckenberg Biodiversity and Climate Research Institute (BiK-F), Senckenberganlage 25, \\ Frankfurt am Main, Germany \\ ${ }^{9}$ Geosciences and Environmental Change Science Center, US Geological Survey, Lakewood, CO, USA \\ ${ }^{10}$ Department of Physical Geography and Ecosystem Science, Lund University, Lund, Sweden \\ ${ }^{11}$ International Center for Climate and Environmental Sciences, Institute of Atmospheric Physics, \\ Chinese Academy of Sciences, Beijing, China \\ ${ }^{12}$ Department of Physics, Imperial College London, London, UK \\ ${ }^{13}$ Laboratoire des Sciences du Climate et de l'Environnement, LSCE/IPSL, CEA-CNRS-UVSQ, Universite Paris-Saclay, \\ Gif-sur-Yvette, France \\ ${ }^{14}$ Max Planck Institute for Chemistry, Mainz, Germany \\ ${ }^{a}$ now at: Deltares, Delft, the Netherlands
}

Correspondence to: Guido van der Werf (guido.vander.werf@vu.nl)

Received: 3 February 2017 - Discussion started: 8 February 2017

Revised: 12 June 2017 - Accepted: 30 June 2017 - Published: 11 September 2017

\begin{abstract}
Fires have influenced atmospheric composition and climate since the rise of vascular plants, and satellite data have shown the overall global extent of fires. Our knowledge of historic fire emissions has progressively improved over the past decades due mostly to the development of new proxies and the improvement of fire models. Currently, there is a suite of proxies including sedimentary charcoal records, measurements of fire-emitted trace gases and black carbon stored in ice and firn, and visibility observations. These proxies provide opportunities to extrapolate emission estimates back in time based on satellite data starting in 1997, but
\end{abstract}

each proxy has strengths and weaknesses regarding, for example, the spatial and temporal extents over which they are representative. We developed a new historic biomass burning emissions dataset starting in 1750 that merges the satellite record with several existing proxies and uses the average of six models from the Fire Model Intercomparison Project (FireMIP) protocol to estimate emissions when the available proxies had limited coverage. According to our approach, global biomass burning emissions were relatively constant, with 10-year averages varying between 1.8 and 2.3 $\mathrm{Pg} \mathrm{C} \mathrm{yr}^{-1}$. Carbon emissions increased only slightly over 
the full time period and peaked during the 1990s after which they decreased gradually. There is substantial uncertainty in these estimates, and patterns varied depending on choices regarding data representation, especially on regional scales. The observed pattern in fire carbon emissions is for a large part driven by African fires, which accounted for $58 \%$ of global fire carbon emissions. African fire emissions declined since about 1950 due to conversion of savanna to cropland, and this decrease is partially compensated for by increasing emissions in deforestation zones of South America and Asia. These global fire emission estimates are mostly suited for global analyses and will be used in the Coupled Model Intercomparison Project Phase 6 (CMIP6) simulations.

\section{Introduction}

Fire is one of the most important disturbance agents in terrestrial ecosystems on a global scale, occurring in all major biomes of the world, and emitting roughly $2-3 \mathrm{Pg} \mathrm{C} \mathrm{yr}^{-1}$, mostly in the form of $\mathrm{CO}_{2}$, but also substantial amounts of reduced species and aerosols (Andreae and Merlet, 2001; van der Werf et al., 2010). Biomass burning activity generally has a strong seasonal cycle and responds to interannual variability (IAV) and trends in plant productivity, land use, and droughts as well as other climatic factors. Droughts tend to increase fire activity in areas with abundant fuel build-up and decrease fire activity in arid regions (Krawchuk and Moritz, 2011; van der Werf et al., 2008). Interactions between climate, humans, and fire are complex and vary both in time and space (Archibald et al., 2009; Bowman et al., 2011). For example, tropical rainforests in their natural state rarely burn. This is a consequence of moist conditions underneath the canopy and a lack of dry lightning ignitions (Cochrane, 2003). Humans have changed that though using fire for agricultural purposes in tropical forest. Land use changes, such as logging and forest fragmentation, increased the forest flammability and number of successful lightning-caused ignitions (Aragão and Shimabukuro, 2010; Cochrane and Laurance, 2008; Fearnside, 2005). Ignitions due to humans have also increased in boreal Asia (Mollicone et al., 2006). However, in many regions, humans also suppress fires, both directly via fire fighting and indirectly by altering the fire seasonality and by modifying fuel build-up through grazing and prescribed burning (Kochi et al., 2010; Le Page et al., 2010; Rabin et al., 2015).

Our knowledge about how these factors have influenced fire emissions over the past centuries or millennia has progressively improved over the past decades, leading to new biomass burning emission inventories (Granier et al., 2011). Dentener et al. (2006) reconstructed fire emissions for the year 1750 by scaling Global Fire Emissions Database (GFED) fire emissions before the satellite era with population derived from the Hundred Year database for In- tegrated Environmental Assessments (HYDE; Klein Goldewijk, 2001), assuming that emissions related to deforestation fires were linearly related to population. For fires not associated with deforestation, only $60 \%$ of the emissions were scaled by population; the remaining $40 \%$ remained constant, assuming that these fires were natural. For high northern latitudes, the fire emissions were doubled in 1750 to account for present-day fire suppression. Other approaches for global fire estimates were often based on the burned area dataset by Mouillot and Field (2005), which consists of gridded data from 1900 onwards, combining the AlongTrack Scanning Radiometer (ATSR) observations with historic literature-based results (land use practices, qualitative reports, and country statistics), and tree ring records. This burned area inventory was used to estimate emissions in the Global Inventory for Chemistry-Climate studies (GICC) dataset (Mieville et al., 2010). GICC provides estimates of biomass burning emissions over the 20th century and emissions mimicked the patterns in burned area with a decrease over the beginning of the 20th century followed by relatively constant emissions until emissions increased rapidly from the 1980s to 2005. The Reanalysis of the Tropospheric chemical composition (RETRO) inventory estimates global wildfire emissions from 1960 to 2000 with a regional approach by collecting and combining literature reviews with different satellite datasets, and a numerical model with a semi-physical approach to estimate fire spread and fire occurrence. From 1960 to 2000, RETRO-based fire emissions showed a global significant increase as a result of an increase in tropical forest and peat soil burning (Schultz et al., 2008). The biomass burning emissions dataset used in the Intergovernmental Panel on Climate Change (IPCC) Fifth Assessment report (AR5) estimated biomass burning emissions from 1850 to 2000 (Lamarque et al., 2010) using a combination of GICC for 1900-1950, the RETRO inventory for the 1960-1997 period, and the satellite-based GFED version 2 for 1997 to 2000 (van der Werf et al., 2006). For the 18501900 time period, biomass burning emissions were held constant because no additional data were available (Mouillot and Field, 2005). The reconstructed global signal indicated that fire emissions were relatively stable until the 1920s. They then decreased until the 1950s, after which they increased until the end of the dataset in 2000 (Lamarque et al., 2010).

Besides these estimates based on historic datasets and satellite data, individual fire models are also used to estimate biomass burning emissions on a global scale (Fig. 1). Over the past decades, these models have been embedded in dynamic global vegetation models (DGVMs), Earth system models (ESMs), and terrestrial ecosystem models (TEMs), enabling studying the feedbacks between fire, vegetation, and climate (Hantson et al., 2016). Fire models have been growing in complexity and a large variety now exist. To better analyse and evaluate these models, the Fire Model Intercomparison Project (FireMIP) was initiated, where models use 


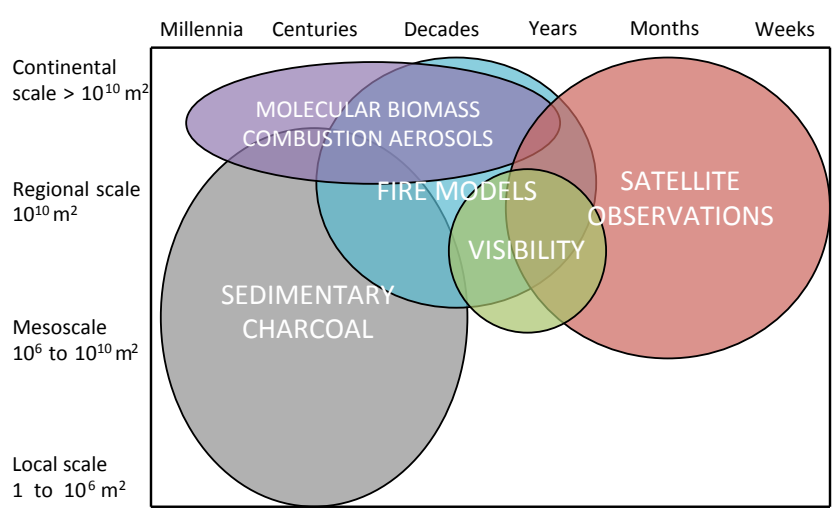

Figure 1. Spatial and temporal resolution of various data streams available to estimate fire emissions (adapted from Kehrwald et al., 2016).

the same forcing (meteorology, lightning, land use, population density, atmospheric $\mathrm{CO}_{2}$ ) datasets (Rabin et al., 2017).

While fire models in general have a global focus, they often do not include anthropogenic fires (for example, those used in the deforestation process). However, another data source is available to estimate these fires and their emissions: the country-level estimates of deforestation and afforestation provided by the United Nations' Food and Agricultural Organization's (FAO) Forest Resource Assessment (FRA) (Food and Agriculture Organization of the United Nations, 2010). These area estimates can be subsequently used in a bookkeeping model to calculate carbon emissions (Houghton, 2003).

All of these emission inventories rely on different datasets and different assumptions. The most consistent estimates of fire patterns are based on satellite-observed burned area or active fires. These usually have a high temporal resolution and are available globally (Fig. 1). These satellite observations are used in combination with a biogeochemical model to estimate fuel loads and calculate emissions in GFED (van der Werf et al., 2010) or using fire-emitted energy scaled to GFED in the Global Fire Assimilation System (GFAS; Kaiser et al., 2012). Unfortunately, these datasets only cover about 2 decades, i.e. since 1997 for GFED and shorter for other datasets, including those based on atmospheric observations of fire-emitted species that can be used to infer emissions when combined with an atmospheric transport model (Edwards et al., 2006; Huijnen et al., 2016; Krol et al., 2013).

Proxy records cover longer timescales, of which the charcoal record is probably the most extensively explored (Daniau et al., 2013; Marlon et al., 2013; Power et al., 2008). Charcoal records can be used for reconstructing fire patterns and emissions on a local to regional scale covering time periods of decades to millennia and beyond. Regional- and global-scale analyses have been done compositing multiple records within a region or globally. The Global Charcoal Database (GCDv3) consists of 736 charcoal records glob- ally, with most samples taken in North America, Europe, Patagonia, and southeast Australia (Marlon et al., 2016). Ice cores are another widely used proxy for retrieving information about fire history on decadal to longer timescales and are representative of regional to continental scales. Reconstructions of continental- to global-scale fire emissions have often been based on concentrations and isotopic signatures of $\mathrm{CO}$ and $\mathrm{CH}_{4}$ (Ferretti et al., 2005; Wang et al., 2010, 2012) because of their relatively long atmospheric lifetime.

These long fire history records most often focus on recent centuries or millennia. The charcoal records suggest that despite close links between fires and humans, pre-industrial fire emissions were not necessarily lower than contemporary rates. The charcoal record also shows that fire has been continuously present in both populated and unpopulated areas since at least the last glacial maximum (Power et al., 2008) with no evidence of major changes in regional fire regime coinciding with the arrival of modern humans in Europe or Australia (Daniau et al., 2010; Mooney et al., 2011). The charcoal-based global analysis of Marlon et al. (2008) indicated a gradual decrease from $1 \mathrm{AD}$ to $1750 \mathrm{AD}$, consistent with a global cooling trend. Over the 16th and 17th centuries, the lowest emissions were observed, coinciding with the climate-driven Little Ice Age (LIA). Based on the concentrations of $\mathrm{CH}_{4}$ and its isotopic ratio, Ferretti et al. (2005) hypothesized that this decrease of human-driven fires in the South American tropics was related to the arrival of Europeans and the introduction of diseases in the tropics, which decimated the population and lowered the number of human ignitions. However, decreased burning is evident in both the Americas and globally (Power et al., 2013) and thus is better explained by widespread cooling during the LIA. Later on, biomass burning emissions increased and peaked in the late 19th century according to these datasets. This peak was also seen in an Antarctic ice core record of CO concentrations and its isotopic ratio (Wang et al., 2010). Observations of $\mathrm{CH}_{4}$ concentrations and its isotopic ratio also indicated an increase; however, this increase continued until the present without a peak in the 19th century (Ferretti et al., 2005). This pattern is also observed in firn air samples in both the Northern Hemisphere (Wang et al., 2012) and Southern Hemisphere (Assonov et al., 2007).

Although biomass burning reconstructions based on isotopic ratios of $\mathrm{CO}$ and those of $\mathrm{CH}_{4}$, as well as those derived from charcoal records, show similar features, there are key differences. These differences are most pronounced for the past 50-100 years and could be the result of different lifetimes of $\mathrm{CO}$ (2 months, thus providing more regional information) and $\mathrm{CH}_{4}$ (about a decade, thus providing information on a global scale), but also because of the distribution of the charcoal datasets, which is denser in temperate regions than in the tropics. Besides this disagreement in trends over the past decade, the amplitude seen in the only known $\mathrm{CO}$ record is much larger than in the $\mathrm{CH}_{4}$ records and is difficult 
to explain with our current understanding of fire emissions (van der Werf et al., 2013).

Field et al. (2009) used horizontal visibility data as observed by weather stations to show how increases in fire emissions were linked to transmigration in Indonesia. Their record started in 1960. A similar approach was used by van Marle et al. (2017) but focused on the Amazon where a similar pattern was found. Combined, these two studies indicated that in the key tropical deforestation regions fire emissions have increased steeply since 1960 .

Finally, ice core and firn records of levoglucosan, a specific biomass burning marker, have enabled the reconstruction of boreal fire emissions for the past two millennia (Kehrwald et al., 2012a; Zennaro et al., 2014) and black carbon concentrations taken from ice cores have been used to reconstruct fossil fuel and biomass burning emissions from boreal sources over the past 220 years (McConnell et al., 2007). Excess ammonium in ice cores has been used as a fire proxy on very long timescales (Fischer et al., 2015), and in rare cases multi-proxy fire reconstructions have also been developed from ice cores (Eichler et al., 2011; Legrand et al., 2016).

To reconstruct fire emissions, there is thus a wide range of information available with its own strengths and weaknesses. The observation-based visibility records provide annual data but are only available for deforestation regions and extend the satellite record only by a few decades. The charcoal data provide a much longer record and are most useful in temperate and boreal regions where data density is highest, but the signals are unitless due to standardization, and it is unknown what each signal exactly represents. Combining these different data sources may provide a more complete history of fire on Earth than focusing on one single line of evidence (Kaiser and Keywood, 2015; Kehrwald et al., 2016). We have reconstructed global fire emissions from 1750 onwards using observation-based data streams (fire emissions based on satellite data for the 1997 period onwards, charcoal datasets in temperate and boreal regions, and visibility records from weather stations in deforestation zones of South America and Indonesia) and multi-model mean emission estimates from FireMIP when no observations were available, and anchored them to satellite-based fire emissions. The new biomass burning (BB) dataset will be most useful for largescale assessments such as the Coupled Model Intercomparison Project Phase 6 (CMIP6) and will be distributed as the BB4CMIP6 database.

\section{Datasets and methods}

To leverage the specific strengths of the various proxies, we divided the globe into the 14 regions used within GFED, which feature relatively homogeneous fire seasons and characteristics, but further subdivided some of these regions to allow input from additional datasets for a total of 17 regions (Fig. 2).

For these 17 regions, we combined the satellite-based emissions from GFED (version 4s; van der Werf et al., 2017) for 1997 to 2015 with either proxies (when available) or fire models to calculate the fire history starting in 1750 (Fig. 3). We used visibility observations from the World Meteorological Organization (WMO) stations in the arc of deforestation (ARCD) and equatorial Asia (EQAS). Dimensionless charcoal records were scaled to the range of the fire models and were used for Europe (EURO) and North America, where boreal and temperate North America was split into eastern (BONA-E, TENA-E) and western (BONA-W, TENA-W) parts. For all other regions, no proxy observations were available, and we used the median of fire model outputs anchored to GFED4s to extrapolate back to 1750 . Both proxies and models were only used to reconstruct annual regional totals; these were distributed over the $0.25^{\circ} \times 0.25^{\circ}$ grid and months based on the GFED4s climatological patterns (19972015). In the next sections, we describe the datasets and methods in more detail.

\subsection{Global Fire Emissions Database (GFED)}

We used the Global Fire Emissions Database version 4 with small fires (GFED4s) for 1997-2015 and as an anchor point for all proxies and model results. In GFED, satellite-derived burned area is used as a key input dataset in a revised version of the Carnegie-Ames-Stanford approach (CASA) biogeochemical model (Potter et al., 1993). The burned area estimates from 2000 onwards are from the Moderate Resolution Imaging Spectroradiometer (MODIS) MCD64A1 $500 \mathrm{~m}$ burned area maps aggregated to $0.25^{\circ} \times 0.25^{\circ}$ spatial resolution and a monthly time step (Giglio et al., 2013). These estimates are "boosted" using a revised version of the small fire estimates of Randerson et al. (2012), which are based on overlying mapped burned area and active fires. Finally, the burned area estimates are used in combination with active fire detections from the Visible and Infrared Scanner (VIRS) and the ATSR sensors to extend this time series back to 1997 (van der Werf et al., 2017).

In CASA, the burned area estimates are then converted to carbon emissions using modelled fuel consumption. Fuel consumption depends on the amount of flammable biomass and combustion completeness, and is calculated in the model as a function of satellite-derived plant productivity, fractional tree cover estimates, and meteorological datasets including solar insolation and moisture levels (van der Werf et al., 2010, 2017). The fuel consumption parameterization in the model was tuned to match observations compiled by van Leeuwen et al. (2014). As a final step, these carbon emission estimates are converted to trace gas and aerosol emissions using emission factors based mostly on the compilation of Akagi et al. (2011), but updates and other sources were used 


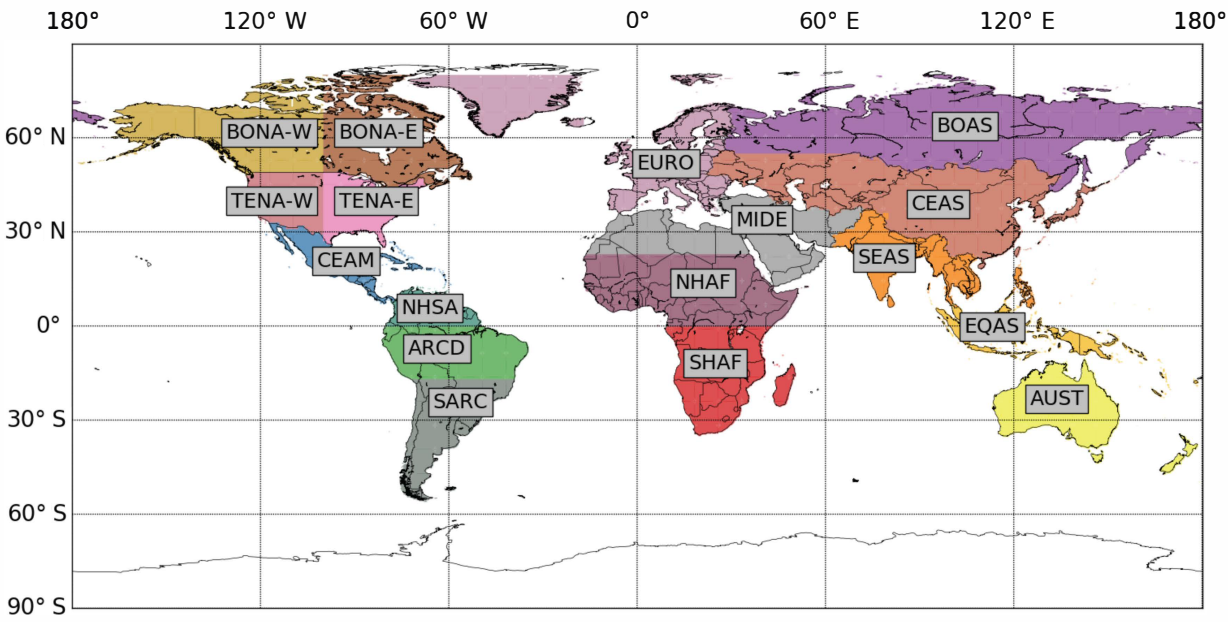

Figure 2. The 17 basis regions used to reconstruct fire emissions; abbreviations are explained in Table 1.

Table 1. Average regional biomass burning emissions (1750-2015) and their relative contribution to the global total emissions. Numbers in parenthesis indicate estimates based on the 5th and 95th percentiles instead of the 25 th and 75 th percentiles used throughout the study to scale the charcoal signal.

\begin{tabular}{llrr}
\hline & & $\begin{array}{r}\text { Average emissions } \\
\left(\mathrm{Tg} \mathrm{C} \mathrm{yr}^{-1}\right)\end{array}$ & $\begin{array}{r}\text { Relative contribution } \\
(\%)\end{array}$ \\
\hline BONA-W & Boreal North America - west & $41.1(39.5)$ & $2.2(2.0)$ \\
BONA-E & Boreal North America - east & $12.5(10.7)$ & $0.7(0.5)$ \\
TENA-W & Temperate North America - west & $8.4(7.9)$ & $0.5(0.4)$ \\
TENA-E & Temperate North America - east & $14.1(107.7)$ & $0.7(5.4)$ \\
CEAM & Central America & 44.5 & 2.4 \\
NHSA & Northern Hemisphere South America & 26.4 & 1.4 \\
ARCD & Arc of deforestation & 53.6 & 2.8 \\
EURO & Europe & $7.0(4.41)$ & $0.4(0.22)$ \\
MIDE & Middle East & 3.1 & 0.2 \\
NHAF & Northern Hemisphere Africa & 475.4 & 25.17 \\
SHAF & Southern Hemisphere Africa & 623.3 & 32.9 \\
BOAS & Boreal Asia & 101.3 & 5.3 \\
CEAS & Central Asia & 78.2 & 4.1 \\
SEAS & Southeast Asia & 207.3 & 10.9 \\
EQAS & Equatorial Asia & 47.3 & 2.7 \\
AUST & Australia & 97.4 & 5.1 \\
SARC & South of the arc of deforestation & 51.3 & 2.7 \\
GLOBE & Sum of all regions & $1896.4(1983.42)$ & 100.0 \\
\hline
\end{tabular}

as well (van der Werf et al., 2017). An overview of the emission factors used in this study is given in Appendix $\mathrm{C}$.

\subsection{Fire models}

The global fire models used here were scaled (Eq. 1) to GFED4s and used in regions where no proxy data were available and were also used to set upper and lower bounds for those regions where charcoal observations were used (Fig. 3). The latter will be described in more detail in Sect. 2.4.
There are generally two types of fire models embedded in global DGVMs. In "process-based models", fires are simulated from a mechanistic point of view, with fire number and size being separately simulated to derive burned area. Fire size simulation often takes into account fire propagation and duration under given weather conditions and is also influenced by fuel state, human suppression, and economic conditions. In contrast, "empirical models" are based on statistical relationships between climate and population density, amongst others, with (usually) burned area (Hantson et al., 2016). Models are developed with different complexity and 


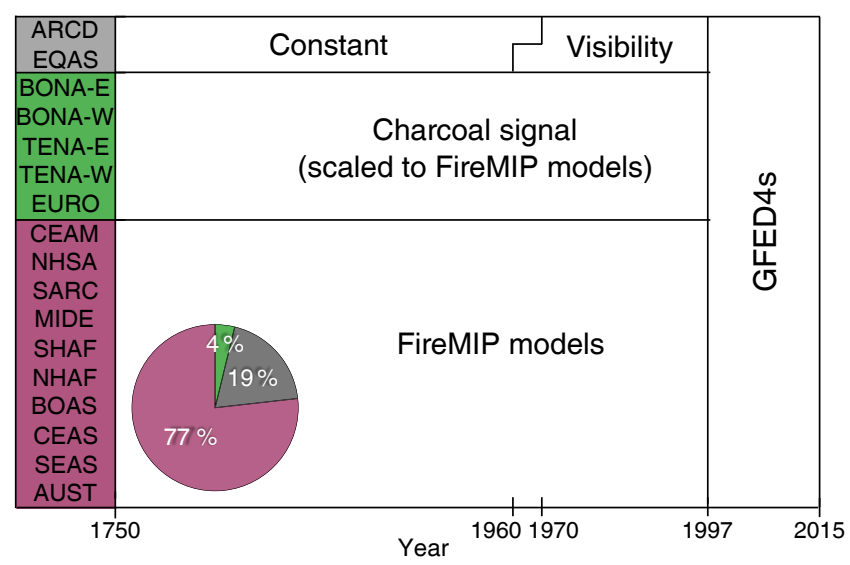

Figure 3. Data sources used for each region. The pie chart represents the contribution of the modelled regions (purple), charcoal regions (green), and visibility regions (grey) to the GFED totals from 1997 to 2015.

some models combine both empirical and process-based approaches. We used carbon emissions of all five models available at the time (14 May 2016) within FireMIP, which covers the 1750-2013 time period, as well as one model that did not participate in FireMIP, the SIMFIRE-GDP model. These six models are described in more detail below. FireMIP's main goal is to evaluate fire models with benchmark datasets to understand differences between models and improve the representation of fires in DGVMs. The models within FireMIP used identical forcing datasets with prescribed meteorological forcing (1901-2013), global atmospheric $\mathrm{CO}_{2}$ concentrations (1750-2013), lightning (1871-2010), land use change (1700-2013), and population density (1700-2013) (Rabin et al., 2017).

We aggregated carbon emissions for each model (mod) and region (reg; Fig. 2) to an annual time step (yr). These estimates were then scaled for each individual model to the regional GFED fire emissions for the overlapping 1997-2003 time period:

$$
\begin{aligned}
\text { FireMIP }_{\text {scaled }}(\mathrm{reg}, \mathrm{yr}, \mathrm{mod}) & =\frac{\text { FireMIP }_{\text {data }}(\mathrm{reg}, \mathrm{yr}, \mathrm{mod})}{\overline{\text { FireMIP }}_{1997: 2003}(\mathrm{reg}, \mathrm{mod})} \\
& \times \overline{\operatorname{GFED}}_{1997: 2003}(\mathrm{reg}),
\end{aligned}
$$

where FireMIP scaled $_{\text {(reg,yr,mod) is the scaled regional model }}$ output on an annual time step and FireMIP 1997:2003 (reg,mod) is the average regional carbon emission estimate for 19972003. While this 7-year time period included the highest fire year (1997) elevated emissions in that year stemmed mostly from peat fires in equatorial Asia for which Eq. (1) is not used to reconstruct fire emissions (See Sect. 2.3). In regions where no proxy information was available and where we therefore only used model output (Fig. 3), fire emissions before 1997 were based on the median of the six FireMIP scaled $_{\text {time se- }}$ ries. We used the average from 1997 to 2003 when combin- ing the various data streams to minimize the impact of interannual variability in the GFED time series, which could result in a mismatch when stitching the FireMIP emissions to the GFED data. Below, we will describe the models we used here, followed by a description of other datasets used and how the various pieces of information were merged to regional time series of emissions for the 1750-2015 period.

\subsubsection{CLM}

The fire module used in the National Center for Atmospheric Research (NCAR) Community Land Model was version 4.5 (CLM4.5). The fire module embedded in CLM consists of four components: non-peat fires outside croplands and tropical closed forests, agricultural fires in croplands, deforestation fires in the tropical closed forests, and peat fires. The first component is process-based, in which burned area is simulated as the product of fire counts and average fire size and regulated by weather and climate, vegetation characteristics, and human activities (Li et al., 2012, 2013). Anthropogenic ignitions and fire suppression are functions of population density and gross domestic product (GDP) per capita; the other three components are empirical ( $\mathrm{Li}$ et al., 2013). Burned area depends on socioeconomic factors, prescribed fire timing, and fuel load for agricultural fires, climate and deforestation rates for tropical deforestation fires, and climate and area fraction of peat exposed to air for peat fires. The simulated burned area is then converted to fire carbon emissions based on simulated biomass and plant functional type (PFT)-dependent combustion completeness factors for leaves, stems, roots, and litter (Li et al., 2012, 2014).

\subsubsection{INFERNO}

The INteractive Fire and Emissions algorithm for Natural envirOnments (INFERNO; Mangeon et al., 2016) model was developed to incorporate a fire parameterization into the Joint UK Land Environment Simulator (JULES) and eventually into an ESM. INFERNO is a reduced-complexity empirical global fire model that builds on the parameterization for fire occurrence from Pechony and Shindell (2009). It estimates burned area and emissions for each of the PFTs used in JULES. Fuel flammability is determined at each time step (using temperature, relative humidity, fuel density, precipitation, and soil moisture). Ignitions are calculated using population density and cloud-to-ground lightning. Burned area is derived from fire occurrence using a fixed average burned area for different vegetation: $0.6,1.4$, and $1.2 \mathrm{~km}^{2}$ for trees, grasses, and shrubs, respectively. Carbon emissions are then estimated using biomass densities from the JULES area and combustion completeness, which scales linearly with soil moisture for leaves (between 0.8 and 1) and stems (between 0 and 0.4). 


\subsubsection{JSBACH, LPJ-GUESS, and ORCHIDEE}

In three of the DGVMs, the SPread and InTensity of FIRE (SPITFIRE) model serves as the fire module (Thonicke et al., 2010). SPITFIRE is a process-based global fire model and a further development of the Reg-FIRM approach (Venevsky et al., 2002) but uses a more complete set of physical representations of spread and fire intensity. Precipitation, daily temperature, wind speed, soil moisture, carbon content of the vegetation and litter pools, and the vegetation distribution are used as input for SPITFIRE to calculate rate of spread, fire duration, and intensity. Based on the calculated burned fraction and post-fire mortality of trees, carbon emissions are computed and redistributed over carbon pools. SPITFIRE includes a dynamic scheme for combustion completeness and depends on fire characteristics and the moisture content of different fuel classes (Lenihan et al., 1998; Thonicke et al., 2010). SPITFIRE was originally developed for the LundPotsdam-Jena (LPJ) vegetation model and is modified for use within the Jena Scheme for Biosphere-Atmosphere Coupling in Hamburg (JSBACH), the Lund-Potsdam-Jena General Ecosystem Simulator (LPJ-GUESS), and the ORganizing Carbon and Hydrology In Dynamic EcosystEms (ORCHIDEE).

The JSBACH land surface model (Brovkin et al., 2013; Reick et al., 2013) is the land component of the Max-PlanckInstitute Earth System Model (MPI-ESM) (Giorgetta et al., 2013). Differences with the original SPITFIRE model are that the vegetation distribution is prescribed and includes two shrub PFTs. The relation between rate of spread and wind speed was modified (Lasslop et al., 2014). Human ignitions and a coefficient related to the drying of fuels were adjusted. Furthermore, the combustion completeness values were updated to better mimic field observations (van Leeuwen et al., 2014).

In contrast to the original LPJ model, the LPJ-GUESS vegetation model (Smith et al., 2001) follows a "gap-model" approach and simulates stochastic establishment and mortality of trees in multiple replicate plots (referred to as patches) for each modelled locality. This allows trees of different sizes and ages to co-exist and thus provides more detailed representation of vegetation structure and dynamics. Therefore, the original SPITFIRE model was integrated into LPJGUESS (Smith et al., 2001) and was adapted to take advantage of these features. Most importantly, the fire characteristics are calculated separately for each patch and the burned area for a patch is interpreted as the probability of a particular patch burning, rather than as a fraction of the locality that burns (Lehsten et al., 2009). As a further consequence of the more detailed vegetation structure, the size-dependent mortality functions in SPITFIRE have a more realistic impact, whereby small trees have a relatively higher probability of being killed by fires than large trees. For the FireMIP simulations used here, further improvements were made; the calculation of human ignitions was recalibrated and post-fire mortality parameters were updated.

For the global vegetation model ORCHIDEE (Krinner et al., 2005), SPITFIRE was adjusted and incorporated by Yue et al. (2014, 2015). Most equations from the original SPITFIRE model were implemented and run parallel to the STOMATE submodule, which simulated vegetation carbon cycle processes in ORCHIDEE. Minor modifications were made by Yue et al. (2014, 2015) and include updated combustion completeness values based on field measurements (van Leeuwen et al., 2014).

\subsubsection{SIMFIRE-GDP}

We used the stand-alone semi-empirical simple fire model (SIMFIRE) coupled to LPJ-GUESS (Knorr et al., 2016), after optimizing SIMFIRE according to Knorr et al. (2014), albeit with a modified semi-empirical function (see Appendix A). SIMFIRE is an empirical global fire model, where burned area estimates are based on human drivers (only population density in the original version) as well as climate and remotely sensed vegetation factors (the fraction of absorbed photosynthetically active radiation (FAPAR; Gobron et al., 2010)) as environmental drivers. The version used here relies additionally on large-region averages of GDP per capita in combination with human population density as statistical drivers for land use impacts on burned area. Simulations with the original coupled LPJ-GUESS-SIMFIRE global dynamic vegetation-wildfire model revealed that over the 20th century population density was the main driver of wildfire emissions, whereas climate factors only had a small influence (Knorr et al., 2016). Therefore, prior to 1900, only GDP and population density are used to rescale emissions computed by LPJ-GUESS-SIMFIRE for the early 20th century. As a result, there is no climate-driven interannual variability prior to 1900 .

\subsection{Visibility-based fire emission estimates}

Fire-emitted aerosols lower visibility, and in the frequently burning regions of EQAS (Field et al., 2009) and ARCD (van Marle et al., 2017) visibility observations can be used as a proxy for fire emissions given the reasonable agreement between fire emission estimates from GFED and visibility observations for the overlapping 1997-2015 period. The visibility observations are taken from weather station records from the NOAA National Centers for Environmental Information (NCEI) Integrated Surface Database (ISD). For EQAS, data are available from 1950 onwards, and for ARCD, data are available starting in 1973. Fire emissions in these regions have increased over time, related to migration of humans accompanied with deforestation (Field et al., 2009; van Marle et al., 2017).

We replaced the visibility-based emissions from 1997 to 2015 with the estimates based on GFED4s (Fig. 4). To extend 


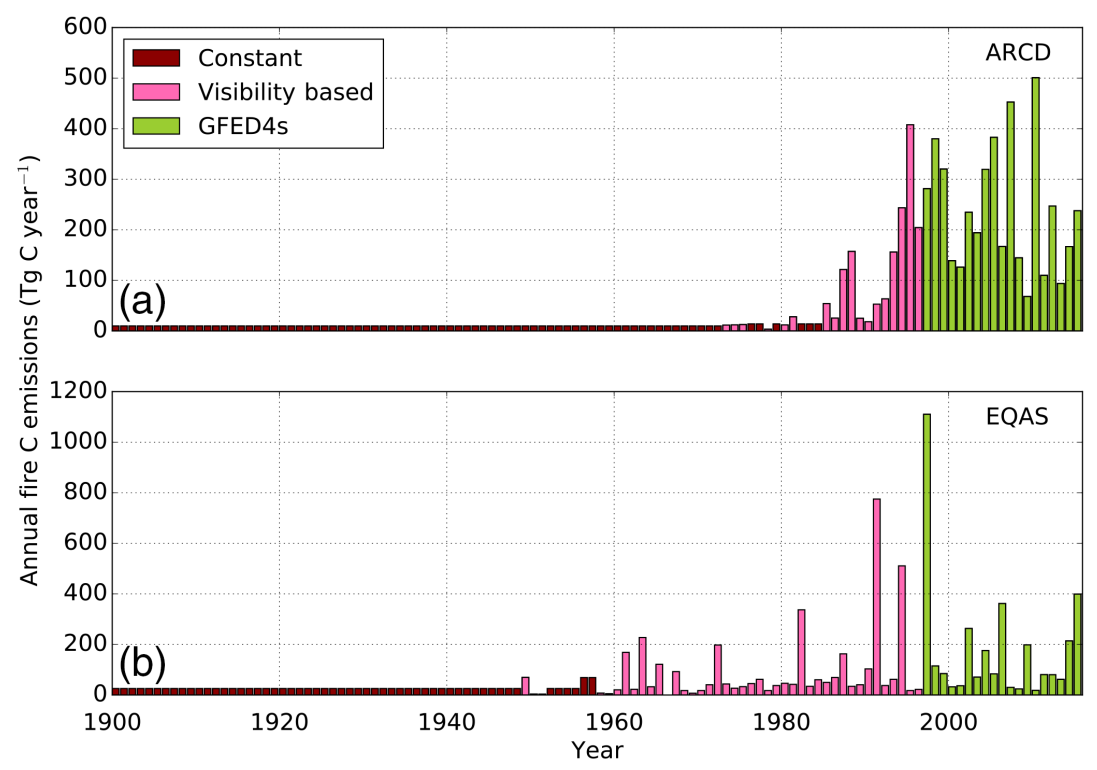

Figure 4. GFED4s-based fire carbon emissions, visibility-based fire carbon emissions, and constant carbon emissions for ARCD (a) and EQAS (b).

this combined time series to years with no visibility observations, we kept the emissions constant at the lowest decadal average. This approach is based on the assumption that fires do not occur naturally in these regions and that fires here are strongly linked to population density (Fearnside, 2005; Field et al., 2009). In the ARCD, deforestation emissions dominate the fire emissions, but additional emissions stem from cerrado burning. We assumed that fraction corresponds to our baseline emissions in the 1970s when deforestation was low and was kept constant before that period. The strong link between population and biomass burning emissions is also seen when comparing HYDE 3.1 population density (Klein Goldewijk et al., 2011) and extended visibility-based fire emissions using the lowest decadal average for the period before visibility observations became available with an $r^{2}$ of 0.67 in the ARCD and an $r^{2}$ of 0.84 in equatorial Asia (both with $p<0.05$ ) over 1750 to 2000 .

\subsection{Global Charcoal Database}

The GCDv3 was, at the time of writing, the most recent version of the GCD (Marlon et al., 2016) and included 736 charcoal records. The records are distributed over five continents with the majority of sites having one record. The sites are not distributed evenly over the globe: many sites (326) are located in the northern part of North America and Europe. Records may lack data from the most recent 250 or so years (the near-surface sediment), which further restricts the charcoal analysis (see Fig. B1, with locations of charcoal sites and regions in Appendix B). While all of our regions have charcoal records, data density is highest in temperate and boreal regions (in total for five regions; Fig. 3). The charcoal records were converted to unitless time series, with a range between 0 and 1, and a decadal time step using methods detailed in Power et al. (2010). The decadal time step was linearly interpolated to annual values and subsequently scaled to the output of the modelled data described under Sect. 2.2 following Eq. (2):

$$
\begin{aligned}
\mathrm{CC}_{\text {FireMIP }}(\text { regyr }) & =\overline{\mathrm{FMIP}}_{25 \text { th }}(\mathrm{reg})+\left(\mathrm{CC}_{\text {norm }}(\mathrm{reg}, \mathrm{yr})\right. \\
& \left.\times\left(\overline{\mathrm{FMIP}}_{75 \text { th }}(\mathrm{reg})-\overline{\mathrm{FMIP}}_{25 \mathrm{th}}(\mathrm{reg})\right)\right),
\end{aligned}
$$

where the normalized charcoal signal $\left(\mathrm{CC}_{\text {norm }}\right)$ is the unitless charcoal influx $z$ score on a decadal time step normalized per region and year following the approach described in Power et al. (2010). Here, a base period of -60 to $200 \mathrm{cal} \mathrm{yr} \mathrm{BP}$ (1750-2010 AD) was used to obtain a common mean and variance for all sites. The composite curves per region were obtained using a locally weighted regression with a window (half) width of 10 years. $\overline{\mathrm{FMIP}}_{25 \text { th }}$ and $\overline{\mathrm{FMIP}}_{75 \text { th }}$ are the average regional 25th and 75th percentiles based on the output of the six FireMIP models for 1750-2000. We used the 25th to 75th percentiles, so outliers did not influence the scaled charcoal signal. To stitch the regional charcoal signal to the GFED period, the charcoal signal adjusted to the FireMIP model output $\left(\mathrm{CC}_{\text {FiremIP }}\right)$ is scaled to the average regional GFED carbon emissions from 1997 to 2003 ( $\overline{\mathrm{GFED}}_{1997: 2003}$; Eq. 3), similar to scaling the FireMIP models to GFED. This is done in the same fashion as when scaling plain model results to GFED, thus averaging out the large interannual variability in fire emissions.

$$
\mathrm{CC}_{\text {scaled }}(\text { regyr })=\frac{\mathrm{CC}_{\text {FireMIP }}(\mathrm{reg}, \mathrm{yr})}{\mathrm{CC}_{\text {FireMIP }}(\mathrm{reg}, 2000)} \times \overline{\mathrm{GFED}}_{1997: 2003}(\mathrm{reg})
$$




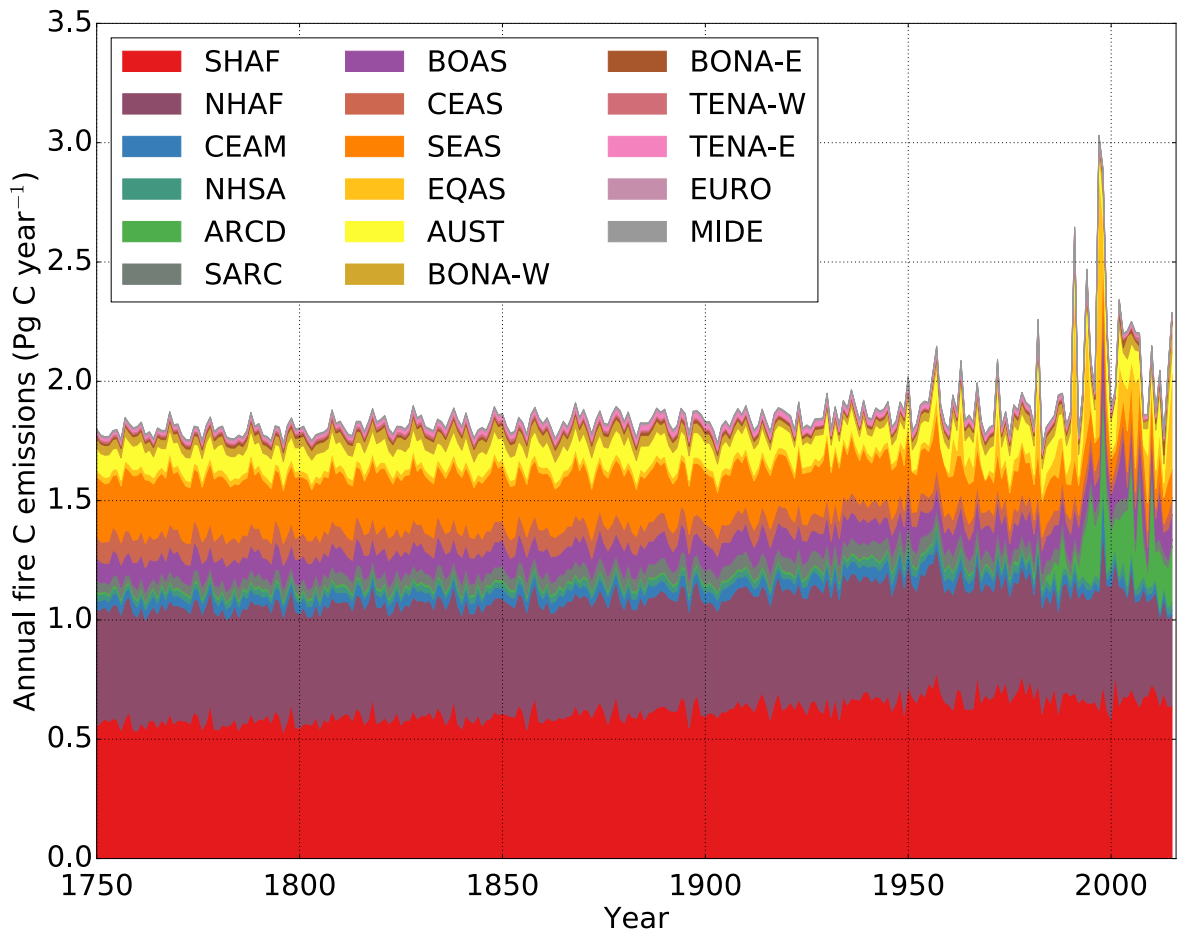

Figure 5. Global biomass burning carbon emissions (1750-2015).

\subsection{Breakdown of regional fire emissions}

The annual regional fire emissions over 1750 to 2015 were distributed over the $0.25^{\circ} \times 0.25^{\circ}$ grid cells based on the GFED4s climatology (1997-2015). We thus assumed that within each region the spatial and monthly patterns did not change over time. Those climate models that already have fire modules and calculate emissions directly may be in a better position regarding estimating spatial and temporal variability based on simulated weather. The contributions of emissions related to deforestation fires, fires in boreal and temperate forests, savanna fires, agricultural waste burning on field, and peatland fires were again based on the GFED climatology. Areas where deforestation and peat fires were important had declining emissions going back in time. Agricultural fires were relatively constant over time, as we did not adjust the relative contribution of these fires due to a lack of information, and fire emissions in these regions did not decline as much as in deforestation zones going back in time. This partitioning was used to convert carbon emissions to the different emissions of several species based on the same emission factors as those used in GFED (Appendix C). The emissions for $\mathrm{BC}, \mathrm{CH}_{4}$, $\mathrm{CO}, \mathrm{H}_{2}, \mathrm{~N}_{2} \mathrm{O}, \mathrm{NH}_{3}$, non-methane volatile organic compounds (NMVOCs), $\mathrm{NO}_{x}$, organic carbon (OC), and $\mathrm{SO}_{2}$ were provided. The NMVOC emissions consist of the sum of $\mathrm{C}_{2} \mathrm{H}_{6}, \mathrm{CH}_{3} \mathrm{OH}, \mathrm{C}_{2} \mathrm{H}_{5} \mathrm{OH}, \mathrm{C}_{3} \mathrm{H}_{8}, \mathrm{C}_{2} \mathrm{H}_{2}, \mathrm{C}_{2} \mathrm{H}_{4}, \mathrm{C}_{3} \mathrm{H}_{6}$, $\mathrm{C}_{5} \mathrm{H}_{8}, \mathrm{C}_{10} \mathrm{H}_{16}, \mathrm{C}_{7} \mathrm{H}_{8}, \mathrm{C}_{6} \mathrm{H}_{6}, \mathrm{C}_{8} \mathrm{H}_{10}$, toluene lump, higher alkenes, higher alkanes, $\mathrm{CH}_{2} \mathrm{O}, \mathrm{C}_{2} \mathrm{H}_{4} \mathrm{O}, \mathrm{C}_{3} \mathrm{H}_{6} \mathrm{O}, \mathrm{C}_{2} \mathrm{H}_{6} \mathrm{~S}$, $\mathrm{HCN}, \mathrm{HCOOH}, \mathrm{CH}_{3} \mathrm{COOH}$, methyl ethyl ketone (MEK), $\mathrm{CH}_{3} \mathrm{COCHO}$, and $\mathrm{HOCH}_{2} \mathrm{CHO}$ (Akagi et al., 2011).

\section{Results}

\subsection{Global fire emissions}

According to our approach, global biomass burning emissions were relatively stable from 1750 to 2015 (Fig. 5). Carbon emissions increased only slightly over the full time period and peaked during the 1990s after which they decreased gradually. Although Africa exhibits a decrease already from 1950 onwards, this decline in emissions was compensated for, especially in the 1990s, by increasing emission in deforestation zones (Fig. 5). From 1960 onwards, the interannual variability increased in our dataset as a result of more detailed information from the visibility-based (1960-1997) and satellite-based (1997-2015) biomass burning emission datasets. The cyclic variability in the first centuries is related to the use of repeating climate variability in FireMIP. While the increase in IAV is thus partly due to changes on underlying data sources, it has also increased in reality because of the increase in deforestation-based emissions that vary more from year to year than other fire emission sources.

The global trend in fire emissions reflects mostly the patterns in biomass burning emissions from Africa, which contributed more than half (58\%) to the global biomass burning 
emissions from 1750 to 2015 (Fig. 6), where Southern Hemisphere Africa (SHAF) contributed more (33\%) than Northern Hemisphere Africa (NHAF, $25 \%$ ). Tropical North and South America (9\%) and tropical Asia (EQAS and southeast Asia (SEAS) combined, $14 \%$ ) are regions substantially influenced by land use change and contributed the most after Africa. These regions are followed by boreal $(8 \%)$ and temperate $(6 \%)$ regions, and Australia (5\%) (Table 1).

\subsection{Regional breakdown of estimates}

\subsubsection{Africa}

The multi-model median indicated that SHAF had a slight increasing trend from 1750 to $\sim 1950$, after which emissions stabilized. Not all models agreed on this; the two models that departed most from the average were SIMFIRE, which had a decreasing trend in fire emissions and highest emissions in pre-industrial times, and ORCHIDEE showing a stronger increasing trend (Fig. 7). In NHAF, emissions were relatively constant from 1750 to the 1950 s, after which the emissions decreased, first slightly and from 1997 onwards more steeply, until the present day (Fig. 7). All models, except CLM, agreed with this decreasing trend. Therefore, the range from the 25th to 75th percentiles was relatively small. The Middle East (MIDE), including the African Sahara, contributed little $(0.2 \%)$ to global emissions. These emissions were stable until 1900, after which they decreased; all models agreed on this trend (Fig. 7).

\subsubsection{South America}

In the ARCD, biomass burning emissions were based on visibility observations from weather stations from 1973 to 1997 and GFED4s emission estimates from 1997 to the present (Fig. 8). According to this approach, fire emissions were constant with $32 \mathrm{Tg} \mathrm{Cyr}^{-1}$ until 1973, after which they stayed relatively low until the first high fire years in 1987 and 1988. After that, fire emissions increased rapidly, with fire emissions of an average of $280 \mathrm{Tg} \mathrm{C} \mathrm{yr}^{-1}$ over the 2000s and highest values often coinciding with El Niño years.

Other tropical regions in South America are Central America (CEAM, contributing 2.4\%), Northern Hemisphere South America (NHSA contributing $1.4 \%$ ), and south of the arc of deforestation (SARC, contributing 2.7\%) (Fig. 8). In these regions, the fire emissions were based on the median of scaled models. The 25th to 75 th percentile range was relatively small, and for all three regions most models showed a decrease from 1950 to the present. In the SIMFIRE model, the decrease started around 1900. In SARC, most models showed an increase until the decrease from 1950 onwards.

\subsubsection{Tropical Asia and Australia}

In EQAS, biomass burning emissions were also based on visibility observations. Here, the emissions were kept constant at $26 \mathrm{Tg} \mathrm{Cyr}^{-1}$ until 1960 based on the average emissions for 1955-1965, when the visibility observations started, after which they increased with large interannual variability (Fig. 9). The highest fire year was 1997, followed by 1991, 1994, and 2015 - all El Niño years. SEAS is another tropical Asian region contributing $11.0 \%$ to the global budget (Fig. 9). Here, the models also showed a decreasing trend over time, where SIMFIRE exposed the highest preindustrial emissions, decreasing strongly from 1950 to the present.

Australia (AUST) contributed $5.2 \%$ to the global fire carbon emissions and the median value is relatively constant over time, with only a small sudden jump in the 1970s. The models exhibited a large range in emissions, where CLM presented higher values in 1750 compared to the other models (Fig. 9).

\subsubsection{Boreal regions}

In both western boreal North America (BONA-W), contributing $2.2 \%$, and eastern boreal North America (BONAE), contributing $0.7 \%$ to the global fire emissions, the number of charcoal records was relatively dense and used here to represent the regional signal with the upper and lower bounds set by the 75th and 25th percentiles of the models (Fig. 10). According to this approach, the levels in biomass burning emissions in BONA-W were about the same in 1750 as in the present day. After a peak in 1850, fire emissions decreased until 1920, after which biomass burning emissions started to increase until the present. Agreement with models was poor; most models showed an increase from 1750 to the present, and only JSBACH and SIMFIRE had a relatively stable period from 1750 to 1900 , after which emission decreased.

In BONA-E, the charcoal signal was relatively constant, which was something most models agreed on. The charcoal signal showed some elevated years just before 1800 and 1900, and after a small decrease, emissions started to increase until present.

Biomass burning emissions in boreal Asia (BOAS, contributing $5.4 \%$ ) were based on the median of the six models. The model simulations showed in general less interannual variability than GFED, and taking their median decreased the variability even further. Also, the median exhibited no clear increasing or decreasing trend; thus, the regional signal stayed relatively constant, while the range between the models was relatively large.

\subsubsection{Temperate regions}

The regions of western temperate North America (TENA$\mathrm{W}$ ), eastern temperate North America (TENA-E), and Europe (EURO) were all based on the charcoal signal (Appendix B) with upper and lower limits based on the models, just like in the boreal regions (Fig. 11). These three regions combined contributed $1.6 \%$ to the global total. The pattern 


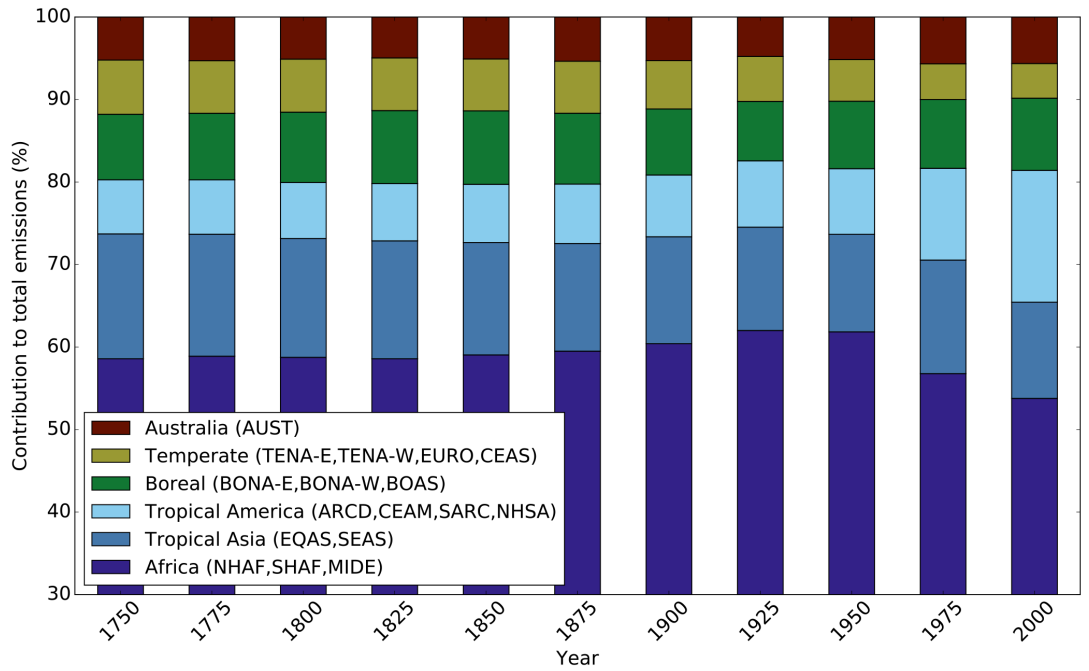

Figure 6. Relative contribution of various regions to global fire emissions. Contributions are calculated as averages over 25 years, except for the 2000-2015 period, which is based on 16 years. Note that the vertical scale starts at $30 \%$.

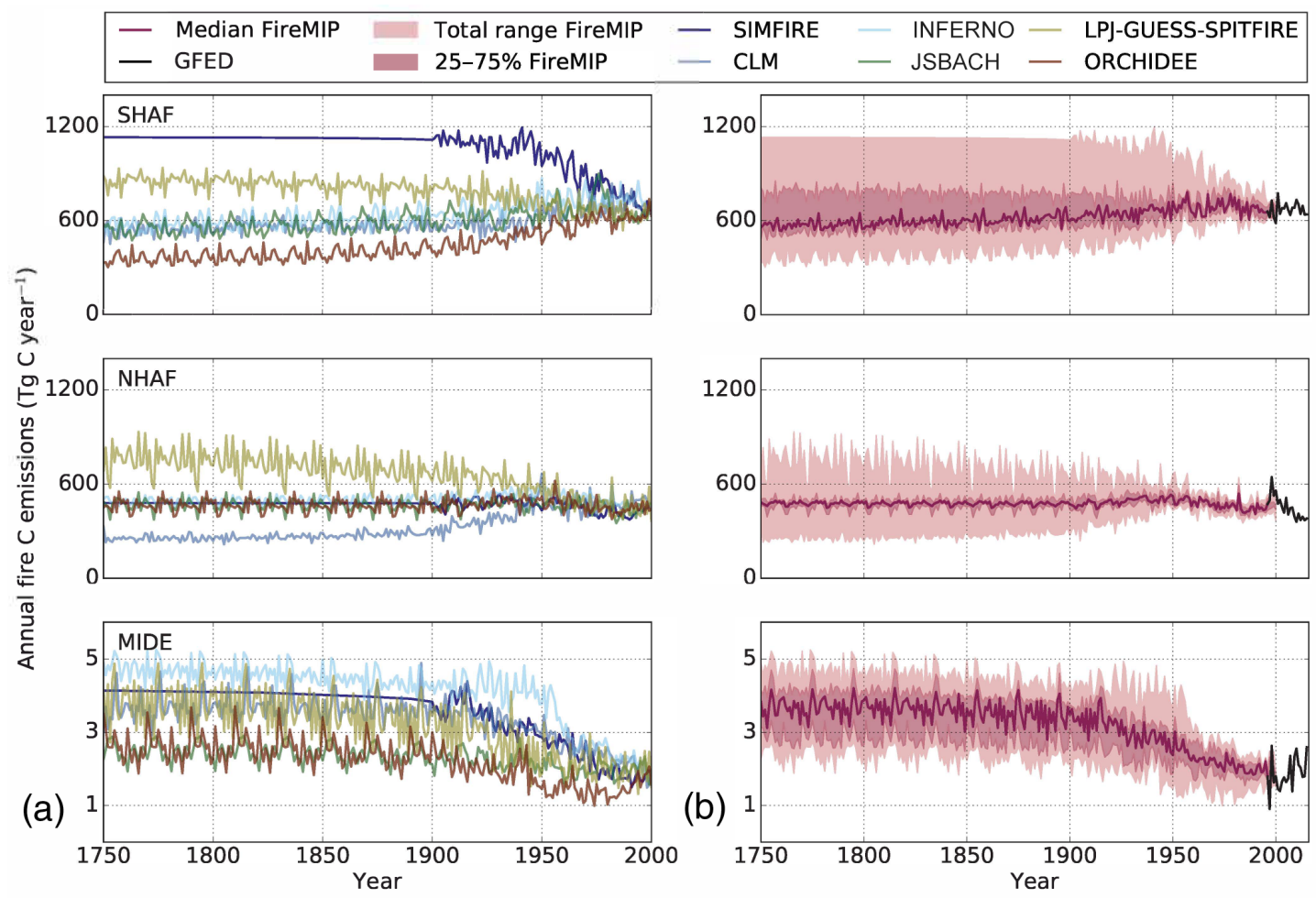

Figure 7. Fire carbon emissions for African regions. Panel (a) indicates all model outputs scaled to the average GFED values for 1997-2003 for that region. Panel (b) indicates the median of the models in purple (solid line) and the GFED signal in black. The variation between the models is shown in pink (25th to 75th percentiles) and light pink (total range models).

based on the charcoal signal in TENA-W showed a peak in 1850, after which fire emissions decreased until 1920. Afterwards, they increased until the present, a pattern similar to the BONA-W trend. The models had a relatively large range, SIMFIRE and CLM exhibited a decrease from 1750 to the present, and all other models were relatively low until 1850 , after which they increased.

The charcoal records in TENA-E indicated relatively constant emissions until 1800, after which emissions increased until a peak in 1900. From 1900 to the present day, emissions 

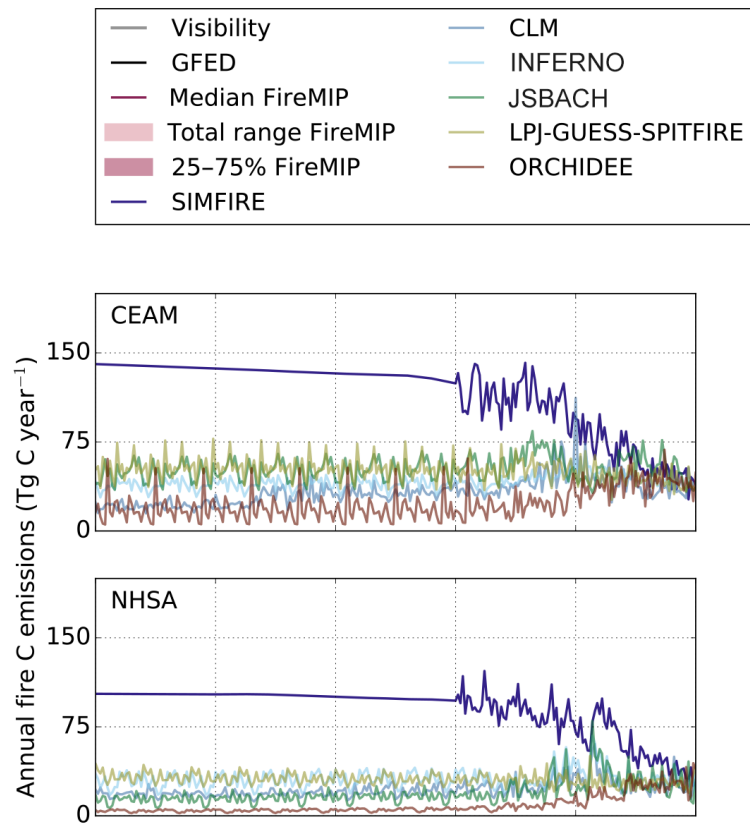

(a)

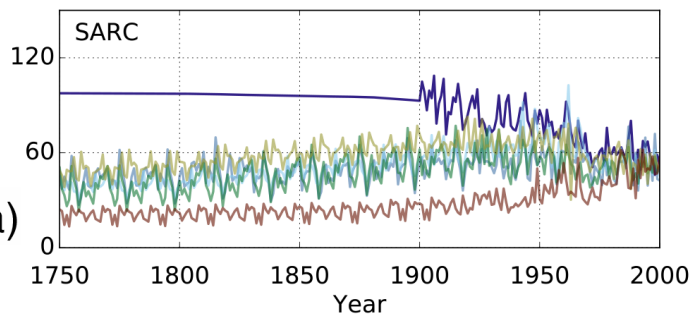

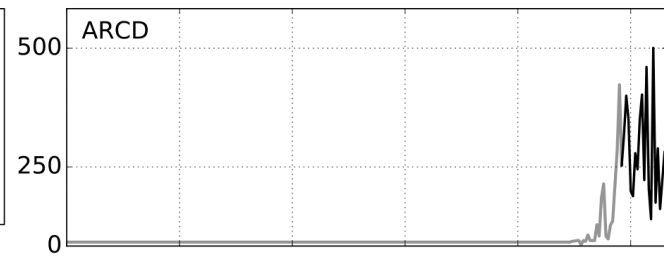
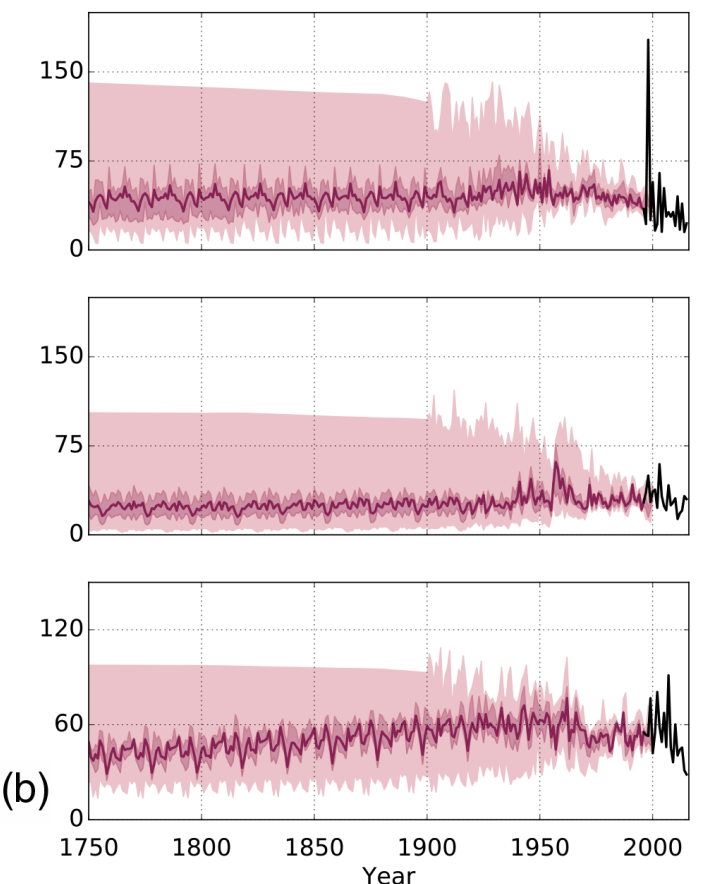

Figure 8. Fire carbon emissions for Central American and South American regions. Panel (a) indicates all model outputs scaled to the average GFED values for 1997-2003 for that region. Panel (b) indicates the visibility-based fire emissions in grey, the median of the models in purple (solid line), and the GFED signal in black. The variation between the models is shown in pink (25th to 75 th percentiles) and light pink (total range models).

decreased again. The 25th to 75th percentiles of the model simulations, used to constrain the charcoal signal, were relatively constant with a small range, resulting in relatively constant fire emissions for this region (Fig. 11).

The charcoal-based trend for EURO is based on records from both southern and northern Europe (Appendix B) and showed an increase from 1750 to the present, whereas the model simulations in general showed no trend or a decrease from 1750 to the present (Fig. 11). Constraining the charcoal signal with the model output resulted in relatively constant fire emissions over Europe from 1750 to the present.

Central Asia (CEAS) is the temperate region which contributed most to the global totals with $4.1 \%$. Biomass burning emissions were based on the median of the models used. Most models, except ORCHIDEE, were relatively constant until 1950, after which emissions decreased. Using the median resulted in biomass burning emissions with a decreasing trend from 1750 to the present (Fig. 11).

\subsection{Sensitivity analyses}

Reconstructing fire emissions is difficult because there are very little data to constrain patterns and the existing data are often conflicting. In this section, we describe the sensitivity of our results to some choices that had to be made rather arbitrarily, including choosing between which percentiles of the model outputs we scaled our results (Sect. 3.3.1) and the choice of the fire models (Sect. 3.3.2).

\subsubsection{Effect of choice of percentiles}

For the regions where we used charcoal as a proxy for fire emissions (Fig. 4), we relied on the 25th to 75th percentiles of the models to scale the charcoal signal (Sect. 2.4). If we had chosen the 5th to 95th percentiles instead, global biomass burning emissions would have increased by $4.6 \%$. This is mainly because TENA-E would have had more than 6 times higher fire emissions during the first part of our record because SIMFIRE results would be included (Fig. 11). This 

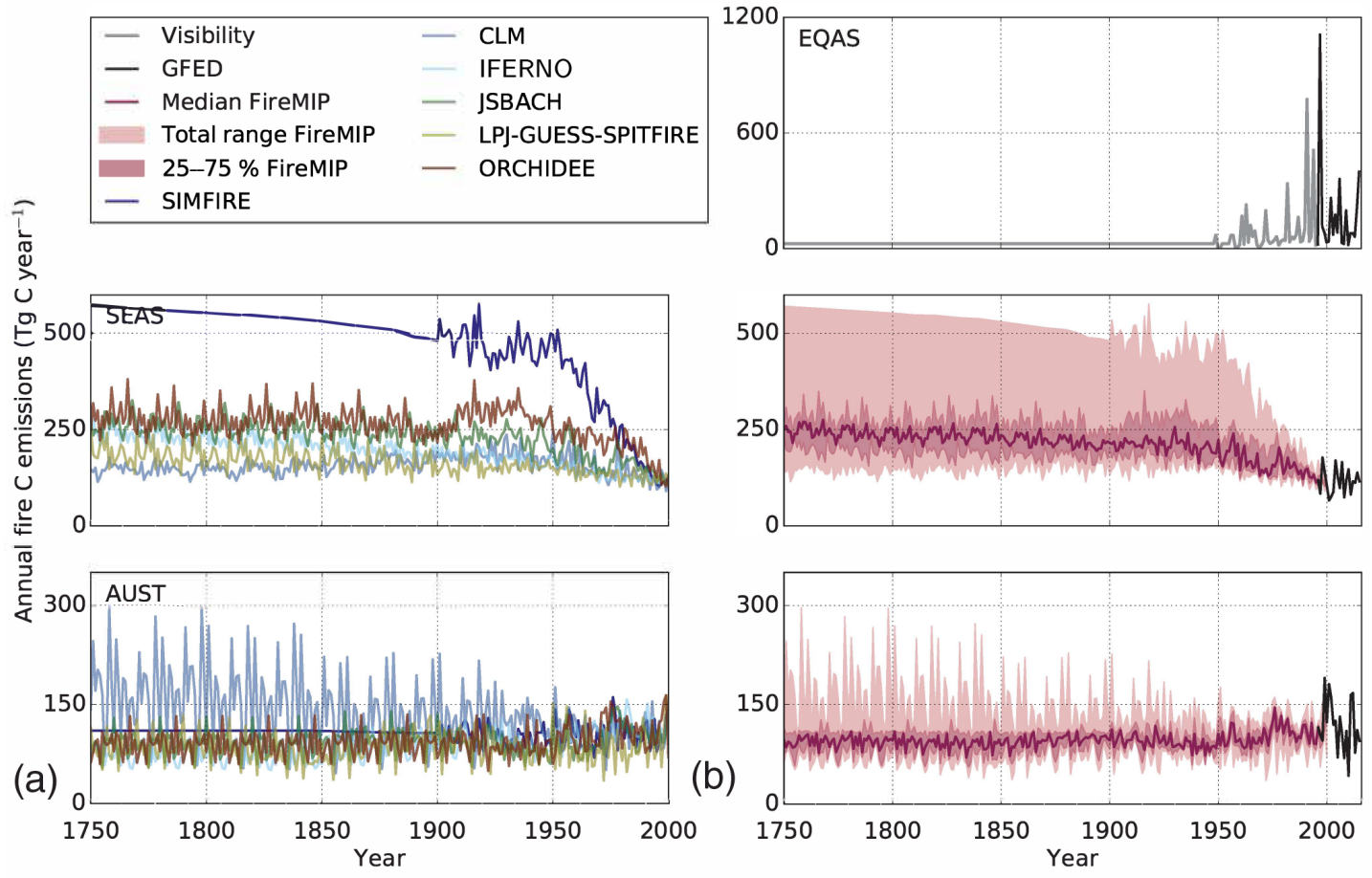

Figure 9. Fire carbon emissions for tropical Asian regions and Australia. Panel (a) indicates all model outputs scaled to the average GFED values for 1997-2003 for that region. Panel (b) indicats the visibility-based fire emissions in grey, the median of the models in purple (solid line), and the GFED signal in black. The variation between the models is shown in pink (25th to 75th percentiles) and light pink (total range models).

would have increased the relative contribution of this region to the global total from 0.74 to $5.43 \%$ (Table 1). EURO and BONA-E would decrease substantially, although those regions were relatively small contributors to the global totals. BONA-W and TENA-W would also have decreased with a relatively small difference $(-3.8$ and $-6.3 \%$ for BONA-W and TENA-W, respectively) (Table 1 ).

\subsubsection{Impact of excluding models on regional emissions}

We used six different models in our regional analyses, all with different temporal patterns. If new proxies become available, benchmarking exercises may indicate which models provide the most reasonable results, but at this stage it is not known which models are best suited for our purpose. To better understand the sensitivity of our results to the selection of the models, we tested what the effect would be on the average regional emissions over 1750-2015 if we excluded one of the six models (Table 2). The estimates from the ARCD and EQAS regions were not based on models and will thus not show any differences.

The effect on the average global totals by excluding models is relatively small (varying from $-3 \%$ for excluding SIMFIRE to +1 or $-1 \%$ for any other model). However, on a regional scale, differences could be profound, with the largest differences again in temperate North America
(TENA-E and TENA-W) where the models exhibited a relatively large range (Fig. 11). In TENA-W, excluding CLM would have increased the average emissions with around $35 \%$ and excluding INFERNO, JSBACH, LPJ-GUESSSPITFIRE, or ORCHIDEE would have increased the average emissions with 19-23\%. In TENA-E, excluding INFERNO or JSBACH would have resulted in the biggest difference with increases of 42-44\%, whereas excluding LPJ-GUESSSPITFIRE or ORCHIDEE would have resulted in a decrease (both $-35 \%$ ). Another region where excluding individual models would have had a relatively large effect is BONAE; excluding SIMFIRE would have resulted in an increase in fire emissions of $21 \%$. However, excluding any other model would have resulted in a decrease, where excluding CLM, INFERNO, and JSBACH had the largest effect (with a decrease around $-20 \%$ ). However, on a global scale, TENA-E, TENA-W, and BONA-W were relatively small contributors (Table 1).

In absolute terms, emissions in SEAS, SHAF, and BOAS were most influenced by excluding one of the models. In SHAF, excluding SIMFIRE or ORCHIDEE would have had the largest effect resulting in a decrease of $20 \mathrm{Tg} \mathrm{C} \mathrm{yr}^{-1}$, excluding SIMFIRE, or an increase of $+20 \mathrm{Tg} \mathrm{C} \mathrm{yr}^{-1}$, excluding ORCHIDEE. Excluding one of the other models would also have had a substantial increase (CLM and JSBACH) or decrease (INFERNO and LPJ-GUESS-SPITFIRE), al- 


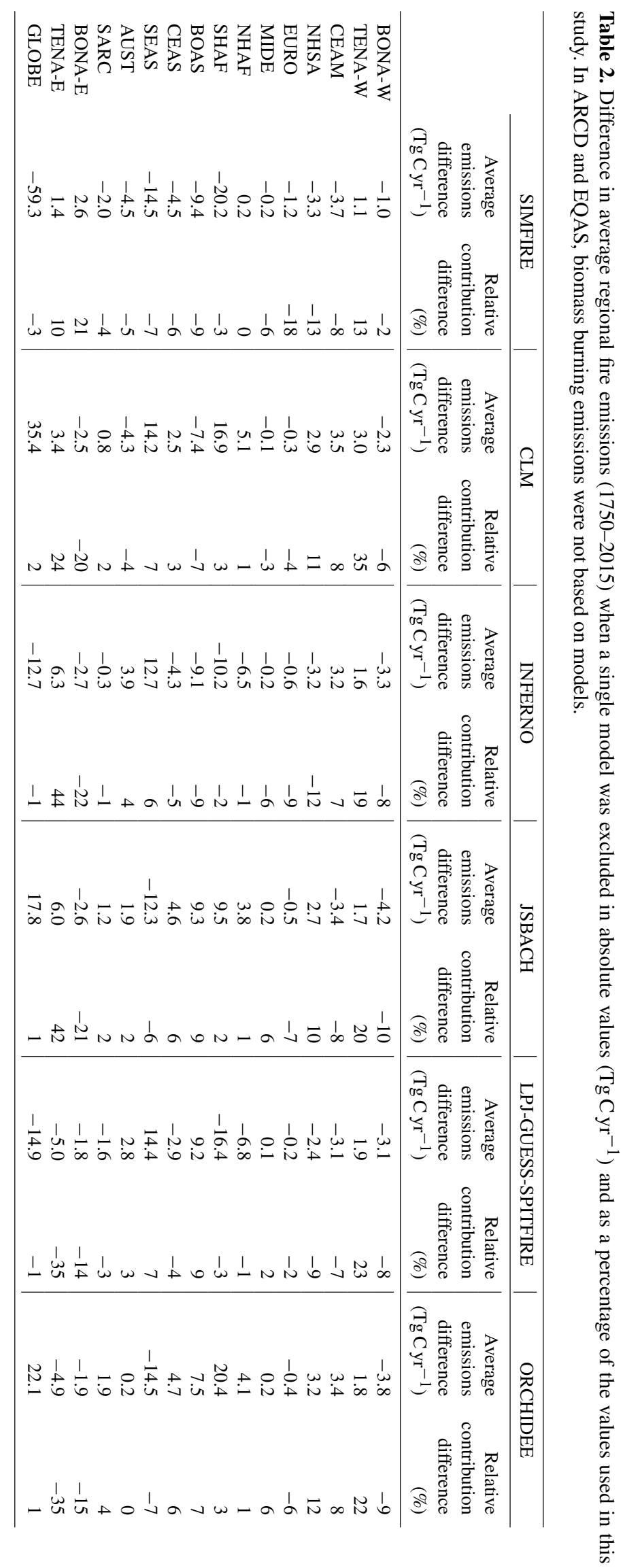




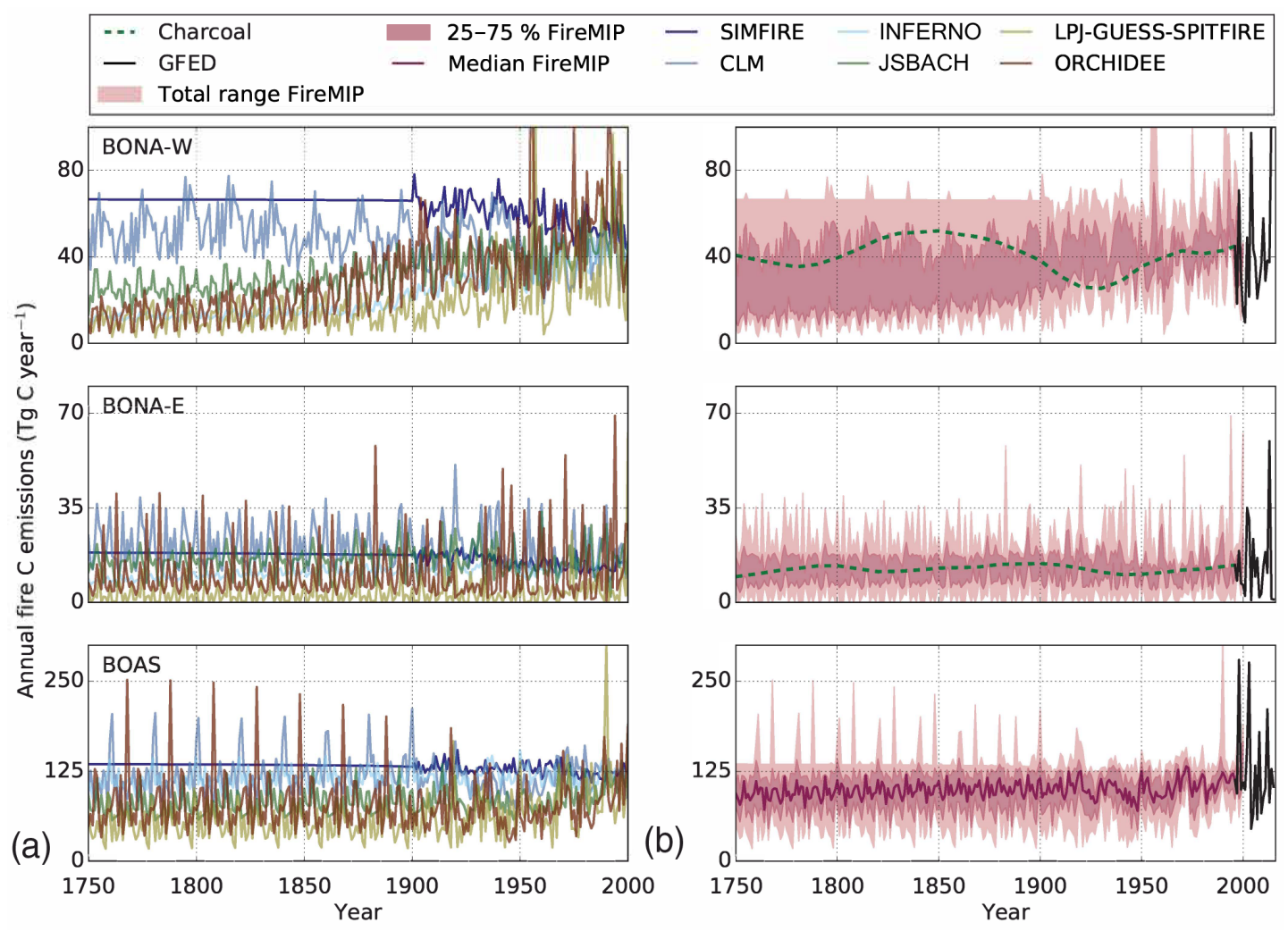

Figure 10. Fire carbon emissions boreal regions. Panel (a) indicates all model outputs scaled to the average GFED values for 1997-2003 for that region. Panel (b) indicates the charcoal signal in green (solid line), the median of the models in purple (solid line), and the GFED signal in black. The variation between the models is shown in pink (25th to 75 th percentiles) and light pink (total range models).

though the relative changes were relatively small (varying from -2 to $+3 \%)$. In SEAS, excluding one of the models would have resulted in either a decrease varying from -12 to

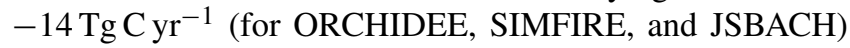
or a increase in the same magnitude varying from +12 to $+14 \mathrm{Tg} \mathrm{C} \mathrm{yr}^{-1}$ (for LPJ-GUESS-SPITFIRE, CLM, and INFERNO). Excluding one of the models in BOAS would have resulted in changes varying from +8 to $9 \mathrm{Tg} \mathrm{C} \mathrm{yr}^{-1}$ (JSBACH, LPJ-GUESS-SPITFIRE, and ORCHIDEE) or -7 to $-9 \mathrm{Tg} \mathrm{Cyr}^{-1}$ (Table 2). In summary, our global numbers were rather insensitive to excluding one of the six models, but on a regional scale differences can be profound.

\section{Discussion}

We found that carbon emissions increased slightly over the full time period and peaked during the 1990s after which they decreased gradually. Africa accounts for a large part (on average, $58 \%$ over our study period) of global fire carbon emissions and the general trend therefore largely mimics that of Africa. The exception is the latter part of our record; from about 1950, African fire emissions decreased while emissions in deforestation zones increased (Fig. 5). From 1960 onwards, the interannual variability increased as a result of more detailed information from the visibility record for EQAS and the ARCD and satellite-based biomass burning emission datasets covering the whole globe. This is thus partly an artefact of data availability but also partly real because the interannual variability from deforestation zones is relatively high and its contribution increased over time. Meteorological forcing data were only available from the year 1901 onwards. The interannual variability before 1901 stems from a 20-year repetitive cycle in meteorological forcing (1901-1920).

The multi-model median indicated that SHAF had an increasing trend from 1750 to $\sim 1950$, after which emissions stabilized. Regional studies based on charcoal show a decrease for African emissions from $\sim 1900$ onwards (Tierney et al., 2010). An explanation for this could be the intensification of agriculture, which suppresses fires in African savannas (Andela and van der Werf, 2014). Based on the relationship between cropland, burned area, and precipitation found in Andela and van der Werf (2014), we reproduced fire emissions back to 1750 , using cropland extent (17502014) from the Land Use Harmonization (LUHv2.2) dataset (Hurtt et al., 2011), in combination with MODIS MCD12C1 cropland for the year 2012. The reconstructed fire emissions based only on precipitation and changes in cropland as in- 


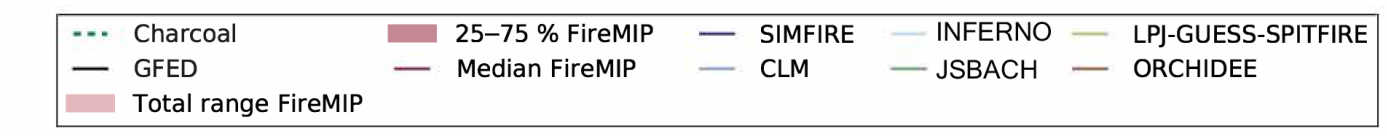
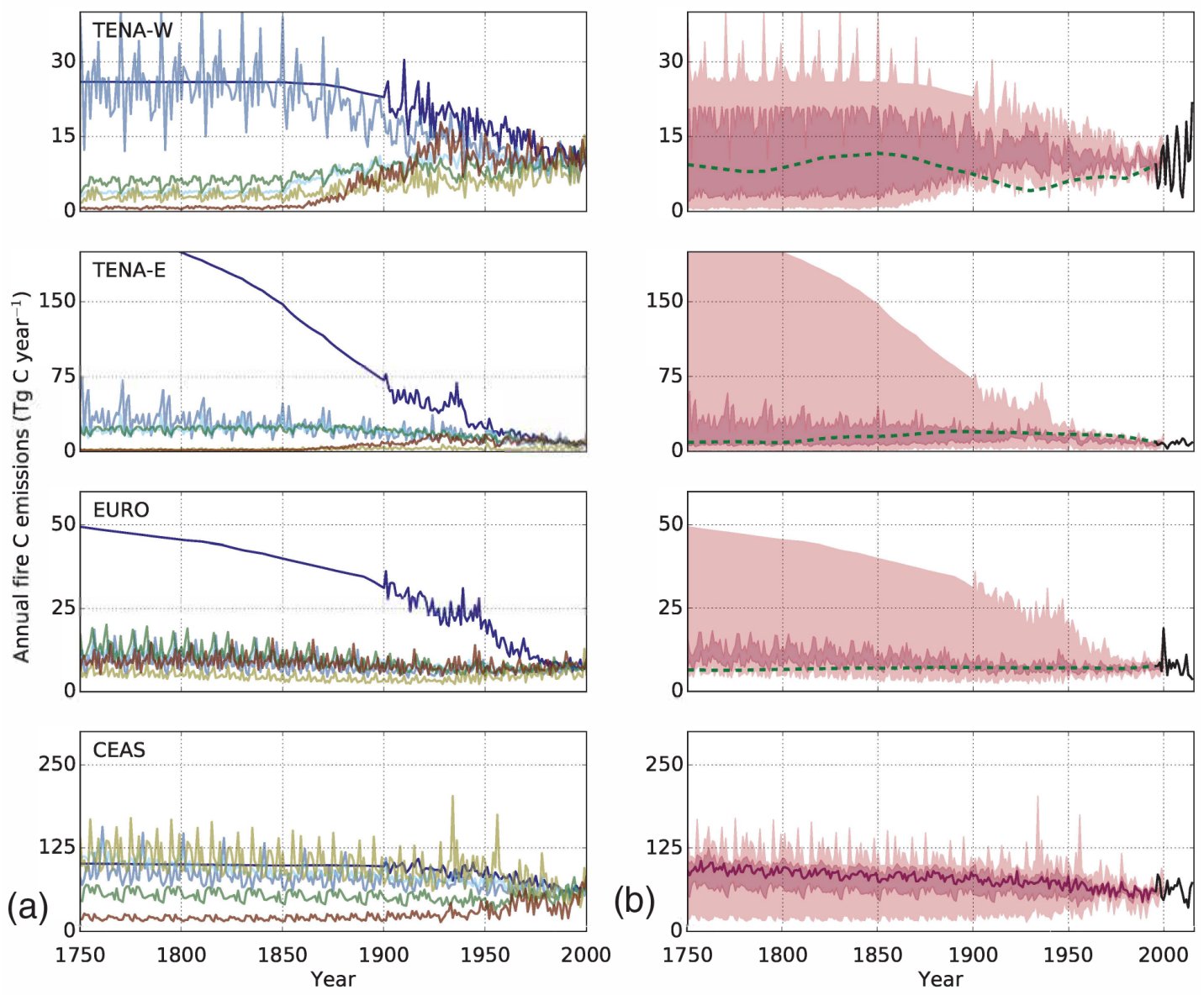

Figure 11. Fire carbon emissions for temperate regions. Panels on the left indicate all model outputs scaled to the average GFED values for 1997-2003 for that region. The panels on the right indicate the charcoal signal in green (solid line), the median of the models in purple (solid line), and the GFED signal in black. The variation between the models is shown in pink (25th to 75th percentiles) and light pink (total range models).

put variables showed similar results as the biomass burning emissions based on the median of models for both Southern Hemisphere and Northern Hemisphere Africa from 1950 to 2013 (Fig. 12). Although the trends for the two approaches over 1700-1950 agree for NHAF, in SHAF they show opposing trends with an increase from 1750 to 1950 based on models and a slight decrease based on the reconstruction. Future research into the drivers of African fires and how these have changed over time could help to improve these estimates.

Emissions from tropical forests are responsible for the global increase we found from 1950 onwards. Rainforests rarely burn in their natural state, due to their generally moist conditions underneath the canopy and because dry lightning is rare (Cochrane, 2003). Logging and land use change made the landscape more vulnerable to fires (Nepstad et al., 1999). Infrastructure projects, including the building of roads and highways, increased the migration into the Amazon basin (Fearnside, 2002; Laurance et al., 2001), but also, for example, the Mega Rice Project during the 1990s where peatland drainage in Kalimantan increased fire emissions in EQAS (Field et al., 2009). Before humans substantially altered the landscape, we assumed that fire emissions did happen, either as a result of man-made factors or naturally, but at a much lower rate. Interannual variability in tropical regions is partly driven by changes in the El Niño-Southern Oscillation (ENSO) for both South America and Indonesia, and the Indian Ocean Dipole (IOD) for Indonesia (Chen et al., 2013; Field et al., 2009).

Over the past decade, several studies have identified larger variability or trends over our study period than we present here. This includes a steeper increase of global fire emissions from 1750 to 1920 than found by us, after which fire emis- 

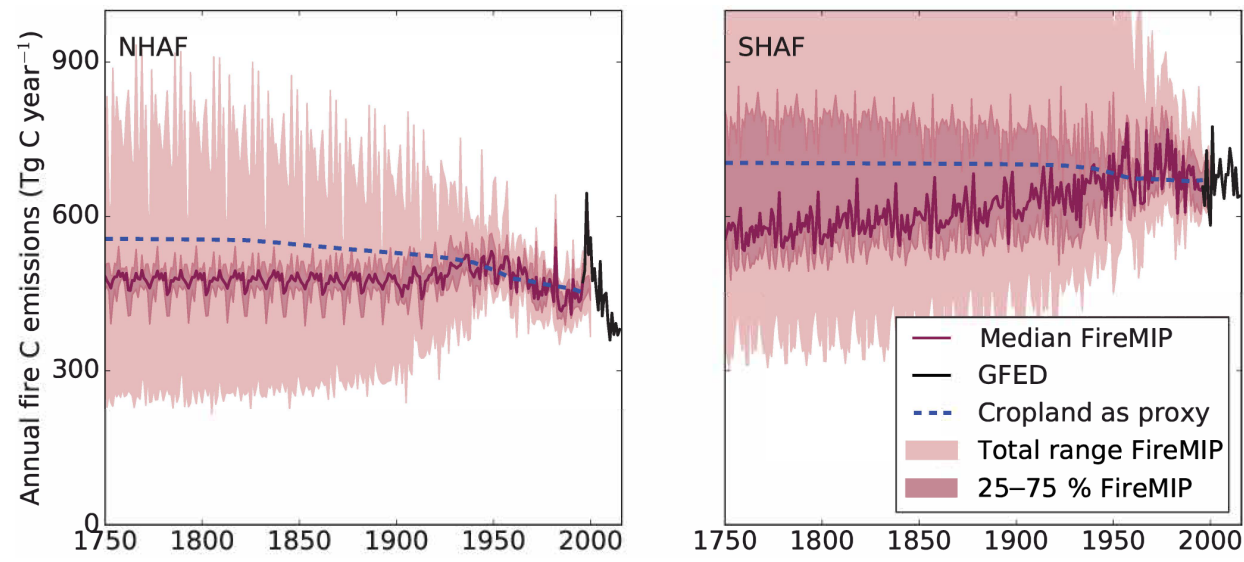

Figure 12. African biomass burning emission estimates from 1750 to 2015 based on models, GFED, and a model based on cropland change as proxy.

sions gradually declined from 1920 to the present based on a global analysis of the charcoal record (Marlon et al., 2008) and much larger variability based on $\mathrm{CO}$ concentrations and their isotopes from a South Pole ice core (Wang et al., 2010). Our results are different than the patterns found when relying solely on charcoal data, because we limited ourselves to that approach for regions where the density of charcoal was relatively large. However, all regions have charcoal records (Appendix B) and results would have been different had we used those.

The variability we found is also smaller than found in the CO record (Wang et al., 2010) whose pattern is difficult to reconcile with our current understanding of fire emissions and atmospheric transport (van der Werf et al., 2013). Other sources of information include the use of $\mathrm{CH}_{4}$ concentrations in ice cores (Ferretti et al., 2005) and firn air samples, although it is uncertain to what degree the most recent part of the record is representative for current conditions. These studies show an increase over the recent decades for both the Northern Hemisphere (Wang et al., 2012) and Southern Hemisphere (Assonov et al., 2007), and at this point we cannot reconcile the differences found in the various records indicating that uncertainty remains substantial.

\subsection{Comparison with CMIP5 estimates}

The biomass burning emissions used in CMIP5 and available for 1850 to 2000 were estimated using GFED version 2 for 1997 onwards and biomass burning inventories (GICC and RETRO) for the pre-satellite era. Biomass burning emissions were kept constant from 1850 to 1900 based on the 1900 value, which was lower than their emission estimates in 2000. From 1900 to 1920, the CMIP5 emissions decreased, after which they increased rapidly to 2000 (Fig. 13; Lamarque et al., 2010). Our results show a somewhat smaller amplitude for most species and less of an increase, although differences vary depending on the specie one is interested in due to the use of revised emission factors and the relative contribution of forest fires (in general emitting high amounts of reduced gases such as $\mathrm{CO}$ and low amounts of $\mathrm{NO}_{x}$ ) versus savanna fires (low $\mathrm{CO}$, high $\mathrm{NO}_{x}$ ) (Fig. 13). Although the global trends are relatively similar, on a regional scale, differences between our estimates and the data used in CMIP5 are more substantial (See Fig. D1, with regional comparisons between CMIP5 and CMIP6 estimates in Appendix D). The largest differences were in TENA-E, TENA-W, SHAF, and SARC. In Africa, the continent from which half of all carbon emissions stems, we found that emissions were relatively flat while CMIP5 estimates increased over the past decades, at odds with recent findings that agricultural expansion lowers fire activity (Andela and van der Werf, 2014). The estimates and trends in EQAS, CEAS, BONA-W, and BONA-E are very similar, and in ARCD as well, although in our estimates the increase there started a few decades later. While our estimates are for several regions driven by consistent data sources, these substantial discrepancies highlight once more that uncertainties are large.

\subsection{Uncertainties}

Uncertainties in reconstructing fire emissions are large and stem from uncertainties in the data we used and from our approach of combining the different datasets. For the reconstruction, the fire models and visibility-based fire emissions were used with GFED4s as an anchor point. We have, to some degree, relied on fire models in almost every region, except ARCD and EQAS. The fire models exhibit differences in regional trends, resulting in a range in regional biomass burning emissions. On a global scale, the impact of excluding single models led to relatively small differences up to $3 \%$ (Table 2). However, on a regional scale, differences were more profound, with percentages up to $44 \%$ in TENA-E. In regions where models were used in combination with charcoal records, the models had a large influence when the char- 

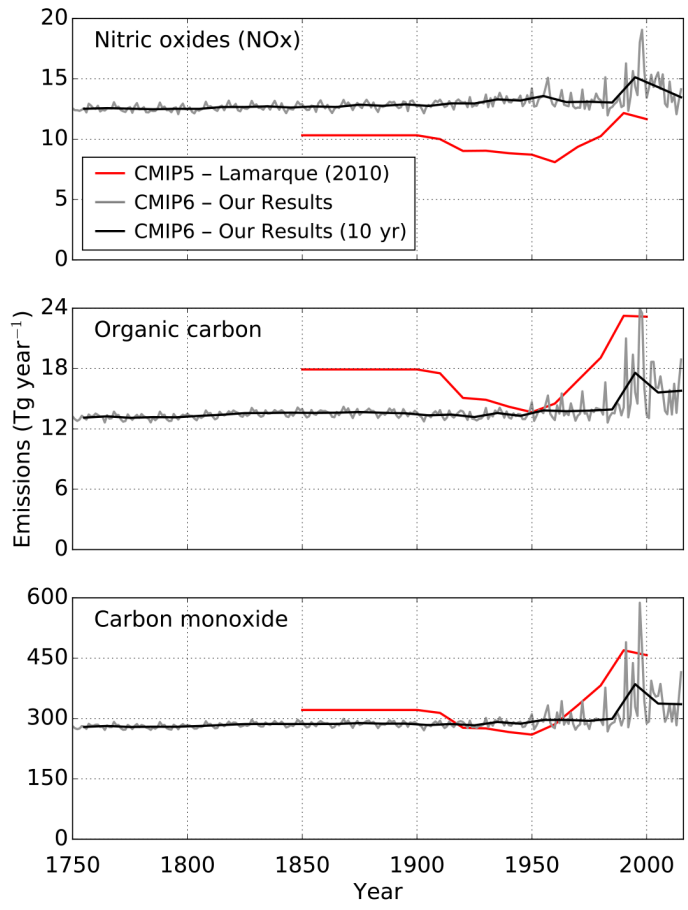

Figure 13. Total global biomass burning emissions for $\mathrm{NO}_{x}$, organic carbon, and carbon monoxide estimated by Lamarque et al. (2010) developed for CMIP5 and our results developed for CMIP6 on annual and decadal time steps.

coal signal and the models exhibited opposing trends (for example, in EURO and BONA-W), and this also explains why in these regions excluding any of the models would result in a decrease in fire emissions (Table 2). Future model comparisons pinpointing the reasons why models behave differently would help constrain this uncertainty. Furthermore, an in-depth comparison between forest fire statistics from the US and Canada, for example, the Canadian Fire Database (CNFDB; Stocks et al., 2002) and the charcoal time series, may help in better constraining trends in boreal and temperate North America.

Given the good agreement between visibility and GFED estimates for the overlapping period in ARCD and EQAS, we feel these regions are relatively well represented. However, this proxy relies on man-made observations leading to inconsistencies. In addition, the locations of the WMO stations were not evenly distributed over the region. Also, little is known about fire history in these regions before visibility observations became available. We have assumed that fire emissions did happen at a much lower rate, either as a result of man-made factors or naturally. However, the relation between climate, humans, and fires is complicated (Archibald, 2016).

Over the 1997-2015 period, we used fire emissions based on GFED4s. In that approach, burned area, fuel consumption, and emission factors all have uncertainties although each parameter has seen important improvements over the past decade. The inclusion of small fires has increased burned area in human-dominated locations, and total burned area now better agrees with higher-resolution burned area in several regions (Mangeon et al., 2015; Randerson et al., 2012). The fire distribution in regions with small fires from, for example, agricultural waste burning, now also agrees better with those in inventories derived from active fire observations (Chuvieco et al., 2016). However, more systematic comparisons are necessary to assess the exact uncertainty in this approach. Likewise, modelled fuel consumption has benefited from comparisons against field measurements compiled by van Leeuwen et al. (2014), and modelled and measured values are now in good agreement on biome level, but comparisons within biomes still show substantial differences (Andela et al., 2016; Veraverbeke et al., 2015). Finally, the emission factors used here from Akagi et al. (2011) distinguish more classes (for example, boreal and temperate regions which were previously lumped together), and the various studies are dealt with in a more systematic way than previously. However, for many species, measurements are lacking and to date we still do not understand the spatial and temporal variability of emission factors well, especially within biomes (Knorr et al., 2012; van Leeuwen and van der Werf, 2011).

GFED fire emissions were also used to distribute the regional annual fire emissions in space and time in the preGFED time period based on the 1997-2015 climatology. This approach ignores variability due to changes in fire weather and land use. For example, in Africa, where many savanna regions have been converted to agricultural land (Andela and van der Werf, 2014), and in EQAS and ARCD where dense tropical rainforest is converted to small-scale agriculture and large-scale industrial agroforestry including infrastructure (Cochrane and Laurance, 2008; Field et al., 2009; Laurance et al., 2001), the spatial pattern has changed over time, which is not accounted for in our approach.

In this study, we have used a regional approach by merging several data sources. There is still much to be gained by collecting more data and using different species. Levoglucosan, for example, is a biomarker for fires and Kehrwald et al. (2012b) showed that levoglucosan in a Greenland ice core represents the fire signal from Asian and North American source regions. Other proxy records that could improve regional estimates are char and soot measurements taken from loess. These can be used to validate the estimates in CEAS (Han et al., 2010). As the Global Charcoal Database continues to evolve with new data contributions (Hawthorne et al., 2017), regions that are currently undersampled could inform GCD-based biomass burning histories. Finally, the FireMIP exercise may lead to a better representation of the processes driving global fire patterns, which itself will help in developing a more complete understanding of fire since the year 1750. For a rough indication of uncertainty in these regions, Fig. 14 shows comparisons between our results, char- 

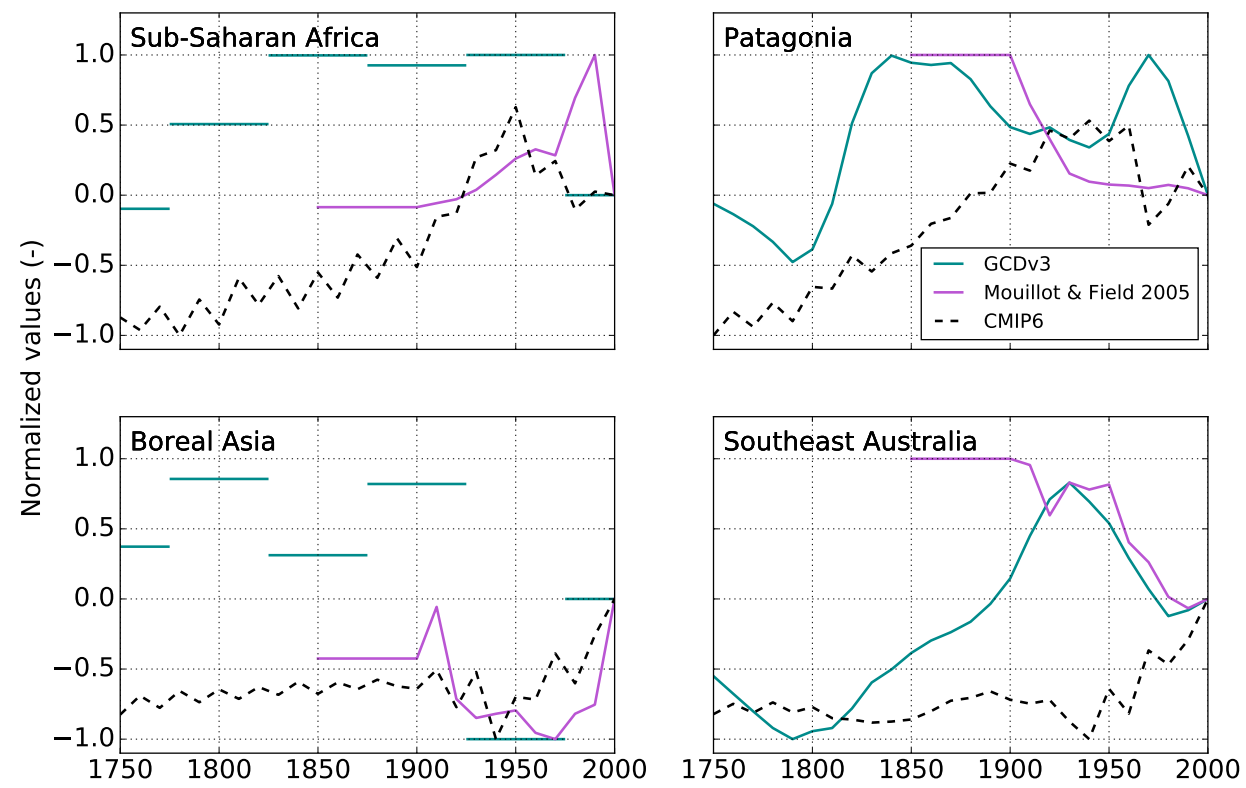

Figure 14. Normalized $z$ scores of charcoal (1750-2013, blue), normalized decadal emissions based on our estimates (1750-2000, black), and normalized emission estimates based on Mouillot and Field (2005) (1850-2000) for sub-Saharan Africa, Patagonia, boreal Asia, and southeast Australia (regions outlined in Appendix B). For sub-Saharan Africa and boreal Asia, charcoal is based on 50-year windows, whereas for Patagonia and southeast Australia 10-year windows were used.

coal $z$ scores (1750-2000) from GCDv3, and burned area reconstruction by Mouillot and Field (1900-2000) for subSaharan Africa, Patagonia, boreal Asia, and southeast Asia (Appendix B). The three datasets quantify fire histories using different units, so all datasets were scaled and transposed to the year 2000 value to qualitatively compare the trends. In sub-Saharan Africa, CMIP6 and GCv3 are similar from 1950 to the present, but CMIP6 decreases more rapidly prior to 1950 (Fig. 14). The trend in boreal Asia also agrees for a large part, where charcoal estimates exhibit a larger range in variation over time. In Patagonia and southeast Asia, the general trend is increasing, although the peak years differ. To improve and constrain our dataset, we encourage paleofire researchers to sample their sites in detail for the last 250 years, even though proxy records are currently mostly used for longer (century to millennial) timescales. Pinpointing the reasons behind outliers and opposing trends between the various models will lead to lower uncertainties for studies focusing on past centuries.

\subsection{Guidance for using this dataset in climate models}

This dataset (v1.2) is made available as a forcing dataset for the Coupled Model Intercomparison Project Phase 6 (CMIP6) analyses at the PCDMI repository (https://pcmdi. llnl.gov/search/input4mips). The emissions for $\mathrm{BC}, \mathrm{CH}_{4}$, $\mathrm{CO}, \mathrm{H}_{2}, \mathrm{~N}_{2} \mathrm{O}, \mathrm{NH}_{3}$, NMVOCs, $\mathrm{NO}_{x}, \mathrm{OC}$, and $\mathrm{SO}_{2}$ were provided. The NMVOC emissions consist of the sum of $\mathrm{C}_{2} \mathrm{H}_{6}, \mathrm{CH}_{3} \mathrm{OH}, \mathrm{C}_{2} \mathrm{H}_{5} \mathrm{OH}, \mathrm{C}_{3} \mathrm{H}_{8}, \mathrm{C}_{2} \mathrm{H}_{2}, \mathrm{C}_{2} \mathrm{H}_{4}$,
$\mathrm{C}_{3} \mathrm{H}_{6}, \mathrm{C}_{5} \mathrm{H}_{8}, \mathrm{C}_{10} \mathrm{H}_{16}, \mathrm{C}_{7} \mathrm{H}_{8}, \mathrm{C}_{6} \mathrm{H}_{6}, \mathrm{C}_{8} \mathrm{H}_{10}$, toluene lump, higher alkenes, higher alkanes, $\mathrm{CH}_{2} \mathrm{O}, \mathrm{C}_{2} \mathrm{H}_{4} \mathrm{O}, \mathrm{C}_{3} \mathrm{H}_{6} \mathrm{O}$, $\mathrm{C}_{2} \mathrm{H}_{6} \mathrm{~S}, \mathrm{HCN}, \mathrm{HCOOH}, \mathrm{CH}_{3} \mathrm{COOH}, \mathrm{MEK}, \mathrm{CH}_{3} \mathrm{COCHO}$, and $\mathrm{HOCH}_{2} \mathrm{CHO}$. These NMVOCs are also provided separately. These are total emissions; ancillary datasets with contribution of emissions related to agricultural waste burning, fires used in deforestation, boreal forest fires, peat fires, savanna fires, and temperate forest fires are provided.

Climate models should not use the $\mathrm{CO}_{2}$ emissions (or nitrogen emissions if the nitrogen cycle is included in the model), as forcing because in general these emissions are not net emissions to the atmosphere, but a return pathway of previously sequestered carbon just as respiration is. The exceptions are $\mathrm{CO}_{2}$ emissions from deforestation and peat fires. However, the models that do not simulate land use change are recommended to use land use change emissions prepared for AR6 (http://www. mpimet.mpg.de/en/science/the-land-in-the-earth-system/ working-groups/climate-biogeosphere-interaction/

landuse-change-emission-data/). Models that have their own fire model but do not simulate anthropogenic fires are advised to use only the emissions related to deforestation and agricultural waste burning. We provide the fraction of emissions associated with this. While the large interannual variability is a key feature of global fire emissions, modelers may consider averaging out this fire signal to avoid having interannual variability in fires being out of sync with interannual variability in climate. 


\section{Conclusions}

We have merged satellite-based fire emissions for recent times, charcoal datasets in temperate and boreal regions, visibility records from weather stations over tropical forest regions, and emission estimates from the FireMIP project. Our aim was to make the best use of the strengths of the various datasets using a regional approach. According to our estimates, global biomass burning carbon emissions increased slightly over the full time period and peaked during the 1990s after which they decreased gradually. The global pattern varies somewhat depending on trace gas or aerosol species. Africa accounts for a large part $(58 \%)$ of global fire carbon emissions and the general trend therefore mimics that of Africa especially in the early part of our record. African fire emissions exhibited a decrease from 1950 onwards as a result of conversion of fire-prone savannas to agricultural land. The absence of pre-industrial fire history data in Africa, in particular, is a major limitation of these estimates. This decrease in Africa is partly offset by increasing emissions in deforestation zones especially during the 1990s, which also led to higher interannual variability in fire emissions. Our results point towards less variability over time than the fire emissions used in CMIP5 and a smaller difference between pre-industrial and present emissions, lowering the impact on changes in atmospheric composition and potentially lowering overall radiative forcing.
Code and data availability. The Python code that was used to assimilate the raw data and construct the gridded emission estimates is available upon request.

This dataset is made available for the Coupled Model Intercomparison Project Phase 6 (CMIP6) analyses at the ESGF repository: at the Earth System Grid Federation (ESGF) repository: https: //esgf-node.llnl.gov/search/input4mips/ (van Marle et al., 2016). GFED4s data are publicly available at http://www.globalfiredata. org/data.html (van der Werf et al., 2017). Charcoal records are available through the Global Charcoal Database version 3: www. paleodata.org (Marlon et al., 2016). Regional visibility-based fire emissions and regional emissions based on the different fire models can be requested from the corresponding author. 


\section{Appendix A: Description and application of the SIMFIRE-GDP model}

In its coupled version, LPJ-GUESS-SIMFIRE uses SIMFIRE to compute burned area based on a stand-alone semi-empirical model optimized against current observations (Knorr et al., 2014). Furthermore, LPJ-GUESS-SIMFIRE uses LPJ-GUESS to compute vegetation dynamics, the biogeochemical cycle (Smith et al., 2001), fire impacts according to Knorr et al. (2012), and a coupling scheme between SIMFIRE and LPJ-GUESS described by Knorr et al. (2016). In contrast to the original version of SIMFIRE, the present version uses regional averages of per capita GDP in addition to human population density as statistical drivers to compute burned area, in addition to climate and vegetation factors. The following non-linear predictor was inverted against GFED3 observed burned area in the same way as described by Knorr et al. (2014) on a global 0.5 by $0.5^{\circ}$ grid excluding croplands:

$A(y)=a(B) F^{b} N_{\max }(y)^{c} \operatorname{logit}(d+e p+f G p)$.

$A$ is fractional burned area (in $\mathrm{yr}^{-1}$ ), $B$ is biome type, $F$ is the multi-year average of the annual maximum fraction of plant-available photosynthetically active radiation (FPAR) derived from satellite observations (Gobron et al., 2010), $N_{\text {max }}$ is the annual maximum Nesterov index divided by $10^{5}$ computed with observed climate data (Weedon et al., 2011), $p$ is population density in $\mathrm{km}^{-2}$ based on HYDE 3.1 for 2005 (Klein Goldewijk et al., 2010), $G$ is gross domestic product per capita in 1995 US dollars (USD) divided by $10^{4}$ where per capita GDP data were taken from HYDE 3.1 for 1995 and the per capita GDP of a grid cell equals that of the region to which the grid cell belongs, and $y$ is the fire year (which starts in a different month at each grid cell before the start of the fire season in the respective grid cell). The term "logit" is the logistic function with $\operatorname{logit}(x)=1 /[1-\exp (-x)]$. GDP data were available for the following regions: Canada, the USA, Central America, South America, north Africa, eastern Africa, southern Africa, west Africa, the Organisation for Economic Co-operation and Development (OECD) Europe, the former Soviet Union, eastern Europe, the Middle East, south Asia, Oceania, Japan, and southeast Asia. Model inversion was carried out for all grid cells simultaneously, optimizing a set of 13 free parameters against annual gridded fractional burned area. The optimal values were $2.32 \times 10^{6}$, $1.12 \times 10^{6}, 0.76 \times 10^{6}, 1.40 \times 10^{6}, 6.27 \times 10^{6}, 10.0 \times 10^{6}$, $0.38 \times 10^{6}$, and $1.69 \times 10^{6}$ for $a(1)$ to $a(8)$ for the eight biomes, and for the global parameters $b=1.007, c=0.75$, $d=-16.0, e=0.0021$, and $f=-0.46$.

Using the coupled LPJ-GUESS-SIMFIRE (Smith et al., 2001) global dynamic vegetation-wildfire model, (Knorr et al., 2016) have found that at least for the first half of the 20th century, climate factors had only a small influence on wildfire emissions, but that the main driver was population density. For extrapolating burned area back in time before 1901, only the part of Eq. (A1) that relates to human factors was used. The optimization of the SIMFIRE-GDP model thus yields a scalar function describing the impact of population density and GDP on fractional burned area, which is

$P(G, p)=\operatorname{logit}[-16+(0.0021-0.46 G) p] / \operatorname{logit}(-16)$.

This scalar $P$ has been normalized to yield a value of 1 in the absence of human activities and therefore describes the degree of human fire suppression. $P$ describes increasing burned area with population density for low GDP, and vice versa for high GDP. GDP data are used for every 5 years from 1890 to 1995 . Before and after that date, we keep per capita GDP per region constant in time. HYDE 3.1 population density values from 1700 to 2000 at a decadal scale were used. Furthermore, historical HYDE 3.1 cropland fraction from 1700 to 2003 was used. The data of Klein Goldewijk et al. (2011) was used to correct SIMFIRE estimates, setting wildfire emissions for croplands to 0 .

To obtain fire emissions spanning the period from 1700 to 2000, LPJ-GUESS-SIMFIRE was run using daily observed climate data (Weedon et al., 2011), yielding annual emissions for the period 1901 to 2000. Emissions for 1700 to 1900 are constructed by multiplying climatological emissions from the early 20th century with a scalar $s$ defined as $s=P \cdot f_{\mathrm{c}}$, where $f_{\mathrm{c}}$ is the cropland fraction. This scalar described the degree of human suppression of burned area as a function of population density, GDP, and cropland fraction. Using $E 1$ as the average annual emission rate computed from the LPJ-GUESS-SIMFIRE during 1901 to $1930, E_{0}$ as the 1901-1930 annual average emissions computed from a separate LPJ-GUESS-SIMFIRE simulation with population density set to zero (no-population emissions), $s_{1}$ as the temporal average of $s$ during 1901-1930, $f=\left(s-s_{1}\right) /\left(1-s_{1}\right), x$ for location, and $t$ for time in years, we compute emissions prior to 1901 as follows:

If $s<s_{1}$ :

$E(t, x)=E_{0}(x) s(t, x) / s_{1}(x)$

else :

$E(t, x)=f(t, x) E_{0}(x)+[1-f(t, x)] E_{1}(x)$. 


\section{Appendix B}

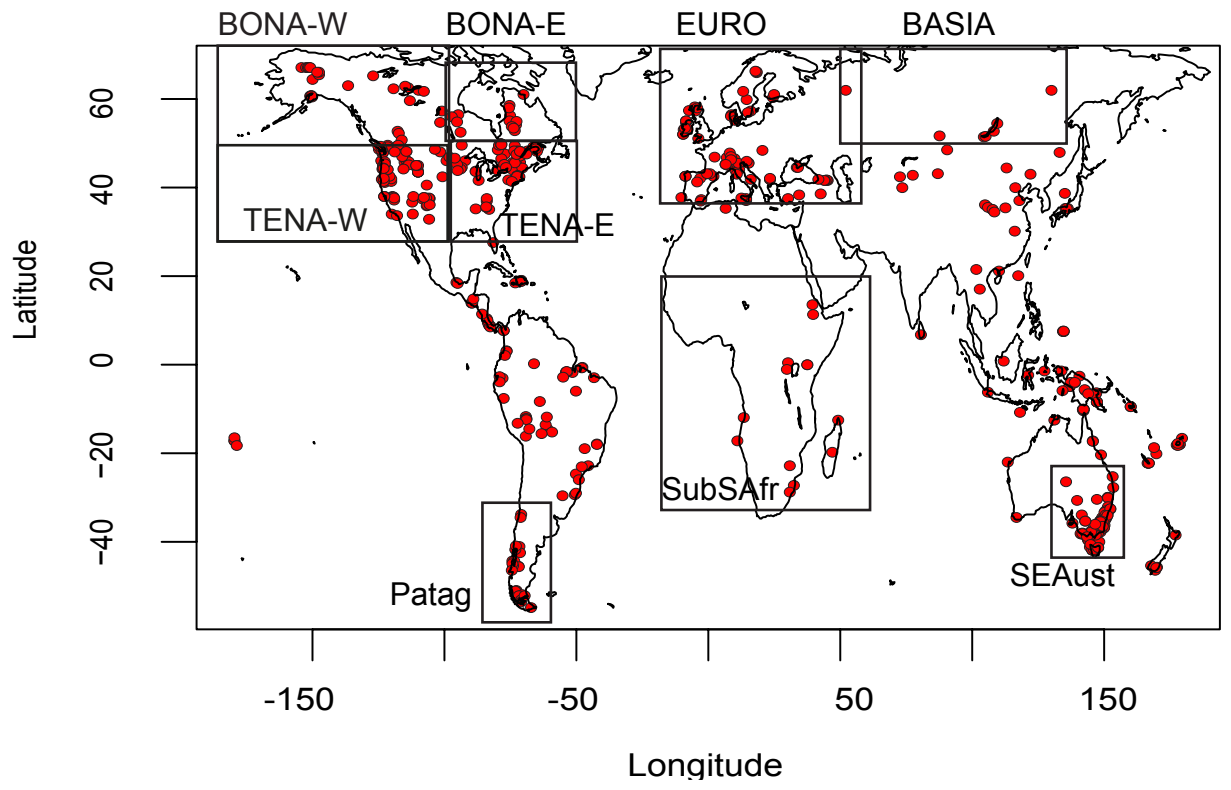

Figure B1. Map with charcoal site locations (red dots) that have samples over the last 250 years and regions (black squares) used in this study. 


\section{Appendix C: Overview of emission factors used in this} study

Table C1. Emission factors in grams of species per kilogram dry matter (DM) burned. Note that $\mathrm{NO}_{x}$ is listed as NO. SAVA: savanna, grassland, and shrubland fires; BORF: boreal forest fires; TEMF: temperate forest fires; DEFO: tropical deforestation and degradation; PEAT: peat fires; and AGRI: agricultural waste burning.

\begin{tabular}{lrrrrrr}
\hline & SAVA & BORF & TEMF & DEFO & PEAT & AGRI \\
\hline $\mathrm{DM}$ & 1000 & 1000 & 1000 & 1000 & 1000 & 1000 \\
$\mathrm{C}$ & 488.27 & 464.99 & 489.42 & 491.75 & 570.05 & 480.35 \\
$\mathrm{BC}$ & 0.37 & 0.5 & 0.5 & 0.52 & 0.04 & 0.75 \\
$\mathrm{CH}_{4}$ & 1.94 & 5.96 & 3.36 & 5.07 & 20.8 & 5.82 \\
$\mathrm{CO}$ & 63 & 127 & 88 & 93 & 210 & 102 \\
$\mathrm{H}_{2}$ & 1.7 & 2.03 & 2.03 & 3.36 & 3.36 & 2.59 \\
$\mathrm{~N}_{2} \mathrm{O}$ & 0.2 & 0.41 & 0.16 & 0.2 & 0.2 & 0.1 \\
$\mathrm{NH}_{3}$ & 0.52 & 2.72 & 0.84 & 1.33 & 1.33 & 2.17 \\
$\mathrm{NO}$ & 3.9 & 0.9 & 1.92 & 2.55 & 1 & 3.11 \\
$\mathrm{OC}_{\mathrm{SO}}$ & 2.62 & 9.6 & 9.6 & 4.71 & 6.02 & 2.3 \\
$\mathrm{SO}_{2}$ & 0.48 & 1.1 & 1.1 & 0.4 & 0.4 & 0.4 \\
$\mathrm{C}_{2} \mathrm{H}_{6}$ & 0.66 & 1.79 & 0.63 & 0.71 & 0.71 & 0.91 \\
$\mathrm{CH}_{3} \mathrm{OH}$ & 1.18 & 2.82 & 1.74 & 2.43 & 8.46 & 3.29 \\
$\mathrm{C}_{2} \mathrm{H}_{5} \mathrm{OH}$ & 0.024 & 0.055 & 0.1 & 0.037 & 0.037 & 0.035 \\
$\mathrm{C}_{3} \mathrm{H}_{8}$ & 0.1 & 0.44 & 0.22 & 0.126 & 0.126 & 0.28 \\
$\mathrm{C}_{2} \mathrm{H}_{2}$ & 0.24 & 0.18 & 0.26 & 0.44 & 0.06 & 0.27 \\
$\mathrm{C}_{2} \mathrm{H}_{4}$ & 0.82 & 1.42 & 1.17 & 1.06 & 2.57 & 1.46 \\
$\mathrm{C}_{3} \mathrm{H}_{6}$ & 0.79 & 1.13 & 0.61 & 0.64 & 3.05 & 0.68 \\
$\mathrm{C}_{5} \mathrm{H}_{8}$ & 0.039 & 0.15 & 0.099 & 0.13 & 1.38 & 0.38 \\
$\mathrm{C}_{10} \mathrm{H}_{16}$ & 0.081 & 2.003 & 2.003 & 0.15 & 0.15 & 0.005 \\
$\mathrm{C}_{7} \mathrm{H}_{8}$ & 0.08 & 0.48 & 0.19 & 0.26 & 1.55 & 0.19 \\
$\mathrm{C}_{6} \mathrm{H}_{6}$ & 0.2 & 1.11 & 0.27 & 0.39 & 3.19 & 0.15 \\
$\mathrm{C}_{8} \mathrm{H}_{10}$ & 0.014 & 0.18 & 0.13 & 0.11 & 0.11 & 0.114 \\
$\mathrm{Toluene} \mathrm{lump}_{\mathrm{Higher}}$ & 0.27 & 1.63 & 0.54 & 0.70 & 4.36 & 0.42 \\
$\mathrm{Higher}_{2}$ alkanes & 0.13 & 0.38 & 0.37 & 0.27 & 0.27 & 0.33 \\
$\mathrm{CH}_{2} \mathrm{O}$ & 0.05 & 0.35 & 0.22 & 0.07 & 0.07 & 0.34 \\
$\mathrm{C}_{2} \mathrm{H}_{4} \mathrm{O}$ & 0.73 & 1.86 & 2.09 & 1.73 & 1.4 & 2.08 \\
$\mathrm{C}_{3} \mathrm{H}_{6} \mathrm{O}$ & 0.57 & 0.77 & 0.77 & 1.55 & 3.27 & 1.24 \\
$\mathrm{C}_{2} \mathrm{H}_{6} \mathrm{~S}$ & 0.16 & 0.75 & 0.54 & 0.63 & 1.25 & 0.45 \\
$\mathrm{HCN}_{\mathrm{HCOOH}}$ & 0.0013 & 0.00465 & 0.008 & 0.00135 & 0.00135 & 0.0013 \\
$\mathrm{CH}_{3} \mathrm{COOH}$ & 0.41 & 1.52 & 0.72 & 0.42 & 8.11 & 0.29 \\
$\mathrm{MEK}_{\mathrm{CH}_{3} \mathrm{COCHO}}$ & 0.21 & 0.57 & 0.28 & 0.79 & 0.38 & 1 \\
$\mathrm{HOCH}_{2} \mathrm{CHO}$ & 0.25 & 0.86 & 0.86 & 0.74 & 0.74 & 0.71 \\
\hline & & & & & &
\end{tabular}


Appendix D: Regional comparison between CMIP6 and

\section{CMIP5}
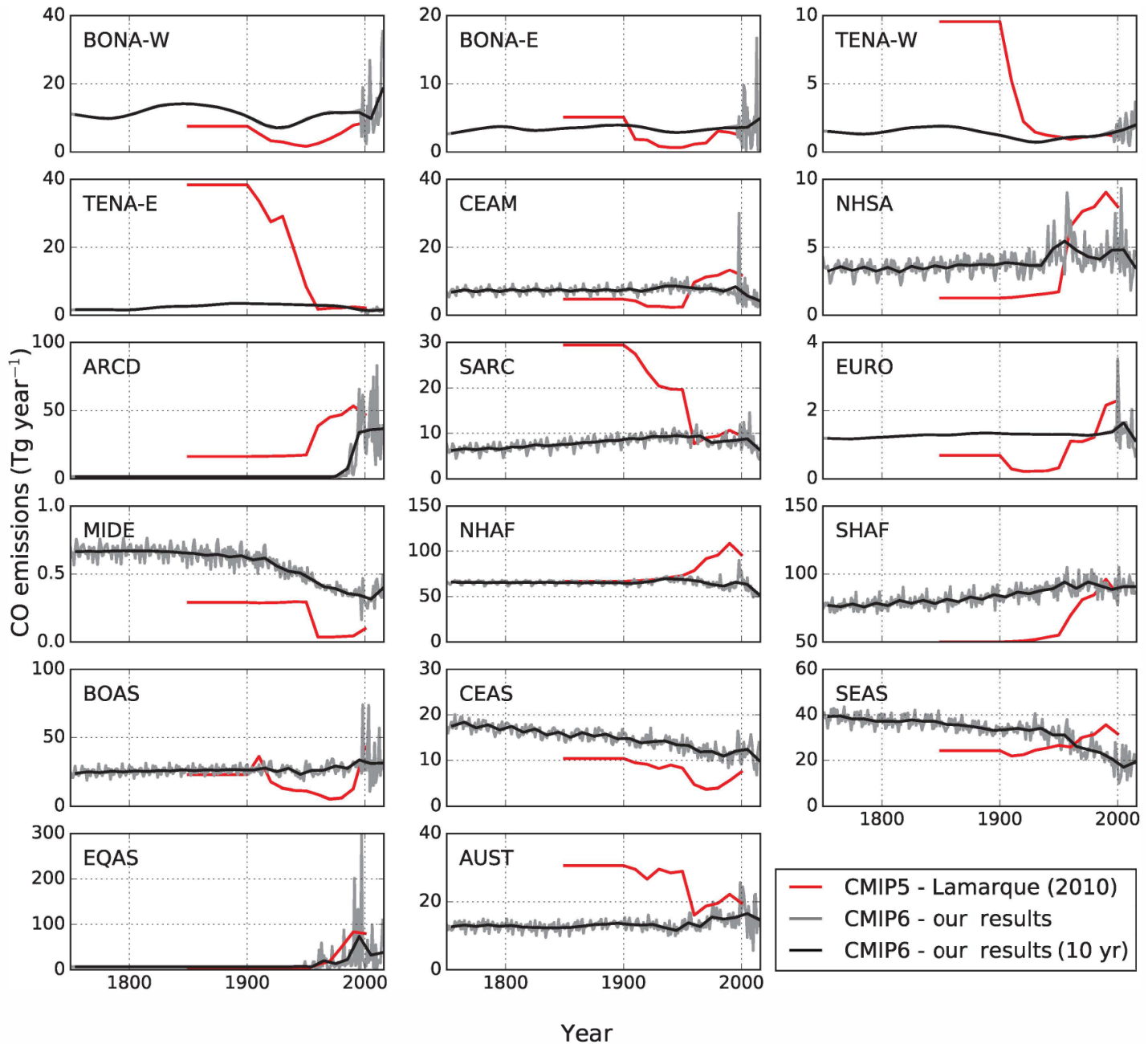

- CMIP5 - Lamarque (2010)

- CMIP6 - our results

- CMIP6 - our results (10 yr)

Figure D1. Regional carbon monoxide biomass burning emissions estimated by Lamarque et al. (2010) for CMIP5 and our results (CMIP6) on annual and decadal time steps. 
Acknowledgements. We would like to thank Kees Klein Goldewijk, Benjamin Aouizerats, Niels Andela, Pierre Friedlingstein, and Thijs van Leeuwen for their help and useful discussions. This work was initiated by Claire Granier, Steven Smith, the CMIP community, and the Interdisciplinary Biomass Burning Initiative (IBBI). Furthermore, we acknowledge the PAGES Global Paleofire Working Group for making the Global Charcoal Database publicly available and supporting fire workshops. Margreet J. E. van Marle and Guido R. van der Werf were supported by the ERC (grant no. 280061). NSF award BCS-1437074 and BCS-1436496 provided workshop support and funding for Jennifer R. Marlon and Brian I. Magi. PICS CNRS 06484 provided workshop support for ALD. Robert D. Field was supported by the NASA Atmospheric Chemistry Modeling and Analysis Program. Stijn Hantson and Almut Arneth acknowledge support by the EU FP7 projects BACCHUS (grant no. 603445) and LUC4C (grant no. 603542). Johannes W. Kaiser was supported by the EU H2020 project MACC-III (grant no. 633080). Wolfgang Knorr acknowledges the support of PEGASOS (EU contract 265148) and BECC (Biodiversity and Ecosystem services in a Changing Climate, funded by the Swedish Government). We thank three anonymous reviewers for their constructive comments and helpful suggestions on an earlier version of the manuscript.

Edited by: Samuel Remy

Reviewed by: three anonymous referees

\section{References}

Akagi, S. K., Yokelson, R. J., Wiedinmyer, C., Alvarado, M. J., Reid, J. S., Karl, T., Crounse, J. D., and Wennberg, P. O.: Emission factors for open and domestic biomass burning for use in atmospheric models, Atmos. Chem. Phys., 11, 4039-4072, https://doi.org/10.5194/acp-11-4039-2011, 2011.

Andela, N. and van der Werf, G. R.: Recent trends in African fires driven by cropland expansion and El Niño to La Niña transition, Nat. Clim. Change, 4, 791-795, https://doi.org/10.1038/nclimate2313, 2014.

Andela, N., van der Werf, G. R., Kaiser, J. W., van Leeuwen, T. T., Wooster, M. J., and Lehmann, C. E. R.: Biomass burning fuel consumption dynamics in the tropics and subtropics assessed from satellite, Biogeosciences, 13, 3717-3734, https://doi.org/10.5194/bg-13-3717-2016, 2016.

Andreae, M. O. and Merlet, P.: Emission of trace gases and aerosols from biomass burning, Global Biogeochem. Cy., 15, 955-966, https://doi.org/10.1029/2000GB001382, 2001.

Aragão, L. E. O. C. and Shimabukuro, Y. E.: The incidence of fire in Amazonian forests with implications for REDD, Science, 328, 1275-1278, https://doi.org/10.1126/science.1186925, 2010.

Archibald, S.: Managing the human component of fire regimes: lessons from Africa, Philos. T. R. Soc. B, 371, 20150346, https://doi.org/10.1098/rstb.2015.0346, 2016.

Archibald, S., Roy, D. P., van Wilgen, B. W., and Scholes, R. J.: What limits fire? An examination of drivers of burnt area in Southern Africa, Glob. Change Biol., 15, 613-630, https://doi.org/10.1111/j.1365-2486.2008.01754.x, 2009.

Assonov, S. S., Brenninkmeijer, C. A. M., Jöckel, P., Mulvaney, R., Bernard, S., and Chappellaz, J.: Evidence for a CO increase in the SH during the 20th century based on firn air samples from
Berkner Island, Antarctica, Atmos. Chem. Phys., 7, 295-308, https://doi.org/10.5194/acp-7-295-2007, 2007.

Bowman, D. M. J. S., Balch, J., Artaxo, P., Bond, W. J., Cochrane, M. A., D’Antonio, C. M., DeFries, R., Johnston, F. H., Keeley, J. E., Krawchuk, M. A., Kull, C. A., Mack, M., Moritz, M. A., Pyne, S., Roos, C. I., Scott, A. C., Sodhi, N. S. and Swetnam, T. W.: The human dimension of fire regimes on Earth, J. Biogeogr., 38, 2223-2236, https://doi.org/10.1111/j.13652699.2011.02595.x, 2011.

Brovkin, V., Boysen, L., Arora, V. K., Boisier, J. P., Cadule, P., Chini, L., Claussen, M., Friedlingstein, P., Gayler, V., van den Hurk, B. J. J. M., Hurtt, G. C., Jones, C. D., Kato, E., de Noblet-Ducoudré, N., Pacifico, F., Pongratz, J., and Weiss, M.: Effect of Anthropogenic Land-Use and Land-Cover Changes on Climate and Land Carbon Storage in CMIP5 Projections for the Twenty-First Century, J. Climate, 26, 6859-6881, https://doi.org/10.1175/JCLI-D-12-00623.1, 2013.

Chen, Y., Morton, D. C., Jin, Y., Collatz, G. J., Kasibhatla, P. S., van der Werf, G. R., DeFries, R. S. and Randerson, J. T.: Longterm trends and interannual variability of forest, savanna and agricultural fires in South America, Carbon Manag., 4, 617-638, https://doi.org/10.4155/cmt.13.61, 2013.

Chuvieco, E., Yue, C., Heil, A., Mouillot, F., Alonso-Canas, I., Padilla, M., Pereira, J. M., Oom, D., and Tansey, K.: A new global burned area product for climate assessment of fire impacts, Global Ecol. Biogeogr., 25, 619-629, https://doi.org/10.1111/geb.12440, 2016.

Cochrane, M. A.: Fire science for rainforests, Nature, 421, 913-919, https://doi.org/10.1038/nature01437, 2003.

Cochrane, M. A. and Laurance, W. F.: Synergisms among Fire, Land Use, and Climate Change in the Amazon, Ambio, 37, 522 527, 2008.

Daniau, A. L., D'Errico, F., and Goñi, M. F. S.: Testing the hypothesis of fire use for ecosystem management by neanderthal and upper palaeolithic modern human populations, PLoS One, 5, e9157, https://doi.org/10.1371/journal.pone.0009157, 2010.

Daniau, A.-L., Sánchez Goñi, M. F., Martinez, P., Urrego, D. H., Bout-Roumazeilles, V., Desprat, S., and Marlon, J. R.: Orbital-scale climate forcing of grassland burning in southern Africa., P. Natl. Acad. Sci. USA, 110, 5069-5073, https://doi.org/10.1073/pnas.1214292110, 2013.

Dentener, F., Kinne, S., Bond, T., Boucher, O., Cofala, J., Generoso, S., Ginoux, P., Gong, S., Hoelzemann, J. J., Ito, A., Marelli, L., Penner, J. E., Putaud, J.-P., Textor, C., Schulz, M., van der Werf, G. R., and Wilson, J.: Emissions of primary aerosol and precursor gases in the years 2000 and 1750 prescribed data-sets for AeroCom, Atmos. Chem. Phys., 6, 43214344, https://doi.org/10.5194/acp-6-4321-2006, 2006.

Edwards, D. P., Pétron, G., Novelli, P. C., Emmons, L. K., Gille, J. C., and Drummond, J. R.: Southern Hemisphere carbon monoxide interannual variability observed by Terra/Measurement of Pollution in the Troposphere (MOPITT), J. Geophys. Res., 111, D16303, https://doi.org/10.1029/2006JD007079, 2006.

Eichler, A., Tinner, W., Brütsch, S., Olivier, S., Papina, T., and Schwikowski, M.: An ice-core based history of Siberian forest fires since AD 1250, Quaternary Sci. Rev., 30, 1027-1034, https://doi.org/10.1016/j.quascirev.2011.02.007, 2011.

Fearnside, P. M.: Avança Brasil: Environmental and Social Consequences of Brazil's Planned Infrastructure in Amazonia, Envi- 
ron. Manage., 30, 735-747, https://doi.org/10.1007/s00267-0022788-2, 2002.

Fearnside, P. M.: Deforestation in Brazilian Amazonia: History, Rates, and Consequences, Conserv. Biol. Ser., 19, 680-688, https://doi.org/10.1111/j.1523-1739.2005.00697.x, 2005.

Ferretti, D. F., Miller, J. B., White, J. W. C., Etheridge, D. M., Lassey, K. R., Lowe, D. C., Macfarling Meure, C. M., Dreier, M. F., Trudinger, C. M., van Ommen, T. D., and Langenfelds, R. L.: Unexpected changes to the global methane budget over the past 2000 years, Science, 309, 1714-1717, https://doi.org/10.1126/science.1115193, 2005.

Field, R. D., van der Werf, G. R., and Shen, S. S. P.: Human amplification of drought-induced biomass burning in Indonesia since 1960, Nat. Geosci., 2, 185-188, https://doi.org/10.1038/ngeo443, 2009.

Fischer, H., Schüpbach, S., Gfeller, G., Bigler, M., Röthlisberger, R., Erhardt, T., Stocker, T. F., Mulvaney, R., and Wolff, E. W.: Millennial changes in North American wildfire and soil activity over the last glacial cycle, Nat. Geosci., 8, 723-727, https://doi.org/10.1038/ngeo2495, 2015.

Food and Agriculture Organization of the United Nations: FAO: Global Forest Resources Assessment 2010, Rome, Italy, available at: http://www.fao.org/forestry/fra/fra2010/en/ (last access: 29 April 2016), 2010.

Giglio, L., Randerson, J. T., and van der Werf, G. R.: Analysis of daily, monthly, and annual burned area using the fourthgeneration global fire emissions database (GFED4), J. Geophys. Res.-Biogeo., 118, 317-328, https://doi.org/10.1002/jgrg.20042, 2013.

Giorgetta, M. A., Jungclaus, J. H., Reick, C. H., Legutke, S., Bader, J., Böttinger, M., Brovkin, V., Crueger, T., Esch, M., Fieg, K., Glushak, K., Gayler, V., Haak, H., Hollweg, H.-D., Ilyina, T., Kinne, S., Kornblueh, L., Matei, D., Mauritsen, T., Mikolajewicz, U., Mueller, W., Notz, D., Pithan, F., Raddatz, T., Rast, S., Redler, R., Roeckner, E., Schmidt, H., Schnur, R., Segschneider, J., Six, K. D., Stockhause, M., Timmreck, C., Wegner, J., Widmann, H., Wieners, K.-H., Claussen, M., Marotzke, J., and Stevens, B.: Climate and carbon cycle changes from 1850 to 2100 in MPI-ESM simulations for the coupled model intercomparison project phase 5, J. Adv. Model. Earth Syst., 5, 572-597, https://doi.org/10.1002/jame.20038, 2013.

Gobron, N., Belward, A., Pinty, B., and Knorr, W.: Monitoring biosphere vegetation 1998-2009, Geophys. Res. Lett., 37, 1-6, https://doi.org/10.1029/2010GL043870, 2010.

Granier, C., Bessagnet, B., Bond, T., D'Angiola, A., Denier van der Gon, H., Frost, G. J., Heil, A., Kaiser, J. W., Kinne, S., Klimont, Z., Kloster, S., Lamarque, J.-F., Liousse, C., Masui, T., Meleux, F., Mieville, A., Ohara, T., Raut, J.-C., Riahi, K., Schultz, M. G., Smith, S. J., Thompson, A., van Aardenne, J., van der Werf, G. R., and van Vuuren, D. P.: Evolution of anthropogenic and biomass burning emissions of air pollutants at global and regional scales during the 1980-2010 period, Climatic Change, 109, 163-190, https://doi.org/10.1007/s10584011-0154-1, 2011.

Han, Y. M., Cao, J. J., Lee, S. C., Ho, K. F., and An, Z. S.: Different characteristics of char and soot in the atmosphere and their ratio as an indicator for source identification in Xi' an, China, Atmos. Chem. Phys., 10, 595-607, https://doi.org/10.5194/acp-10-5952010, 2010.
Hantson, S., Arneth, A., Harrison, S. P., Kelley, D. I., Prentice, I. C., Rabin, S. S., Archibald, S., Mouillot, F., Arnold, S. R., Artaxo, P., Bachelet, D., Ciais, P., Forrest, M., Friedlingstein, P., Hickler, T., Kaplan, J. O., Kloster, S., Knorr, W., Lasslop, G., Li, F., Mangeon, S., Melton, J. R., Meyn, A., Sitch, S., Spessa, A., van der Werf, G. R., Voulgarakis, A., and Yue, C.: The status and challenge of global fire modelling, Biogeosciences, 13, 3359-3375, https://doi.org/10.5194/bg-13-3359-2016, 2016.

Hawthorne, D., Courtney Mustaphi, C. J., Aleman, J. C., Blarquez, O., Colombaroli, D., Daniau, A.-L., Marlon, J. R., Power, M., Vannière, B., Han, Y., Hantson, S., Kehrwald, N., Magi, B., Yue, X., Carcaillet, C., Marchant, R., Ogunkoya, A., Githumbi, E. N., and Muriuki, R. M.: Global Modern Charcoal Dataset (GMCD): A tool for exploring proxy-fire linkages and spatial patterns of biomass burning, Quaternary Int., https://doi.org/10.1016/j.quaint.2017.03.046, in review, 2017.

Houghton, R. A.: Revised estimates of the annual net flux of carbon to the atmosphere from changes in land use and land management 1850-2000, Tellus B, 55, 378-390, https://doi.org/10.1034/j.1600-0889.2003.01450.x, 2003.

Huijnen, V., Wooster, M. J., Kaiser, J. W., Gaveau, D. L. A., Flemming, J., Parrington, M., Inness, A., Murdiyarso, D., Main, B., and van Weele, M.: Fire carbon emissions over maritime southeast Asia in 2015 largest since 1997, Sci. Rep., 6, 26886, https://doi.org/10.1038/srep26886, 2016.

Hurtt, G. C., Chini, L. P., Frolking, S., Betts, R. A., Feddema, J., Fischer, G., Fisk, J. P., Hibbard, K., Houghton, R. A., Janetos, A., Jones, C. D., Kindermann, G., Kinoshita, T., Klein Goldewijk, K., Riahi, K., Shevliakova, E., Smith, S., Stehfest, E., Thomson, A., Thornton, P., van Vuuren, D. P., and Wang, Y. P.: Harmonization of land-use scenarios for the period 1500-2100: 600 years of global gridded annual land-use transitions, wood harvest, and resulting secondary lands, Climatic Change, 109, 117 161, https://doi.org/10.1007/s10584-011-0153-2, 2011.

Kaiser, J. W. and Keywood, M.: Preface for Atmos. Env. Special issue on IBBI, Atmos. Environ., 121, 1-3, https://doi.org/10.1016/j.atmosenv.2015.10.033, 2015.

Kaiser, J. W., Heil, A., Andreae, M. O., Benedetti, A., Chubarova, N., Jones, L., Morcrette, J.-J., Razinger, M., Schultz, M. G., Suttie, M., and van der Werf, G. R.: Biomass burning emissions estimated with a global fire assimilation system based on observed fire radiative power, Biogeosciences, 9, 527-554, https://doi.org/10.5194/bg-9-527-2012, 2012.

Kehrwald, N., Zangrando, R., Gabrielli, P., Jaffrezo, J. L., Boutron, C., Barbante, C., and Gambaro, A.: Levoglucosan as a specific marker of fire events in Greenland snow, Tellus Ser. B, 64, 1-9, https://doi.org/10.3402/tellusb.v64i0.18196, 2012a.

Kehrwald, N., Zennaro, P., and Barbante, C.: Increasing fire activity in a warming climate? Ice core record insights from the present and the last interglacials, Pages NEWS, 21, 16-17, $2012 \mathrm{~b}$.

Kehrwald, N. M., Aleman, J. C., Coughlan, M., Courtney Mustaphi, C. J., Githumbi, E. N., Magi, B. I., Marlon, J. R., and Power, M. J.: One thousand years of fires: Integrating proxy and model data, Front. Biogeogr., 8, 155-159, 2016.

Klein Goldewijk, K.: Estimating global land use change over the past 300 years: The HYDE Database, Global Biogeochem. Cy., 15, 417-433, https://doi.org/10.1029/1999GB001232, 2001.

Klein Goldewijk, K., Beusen, A., and Janssen, P.: Long-term dynamic modeling of global population and built-up area in 
a spatially explicit way: HYDE 3.1, Holocene, 20, 565-573, https://doi.org/10.1177/0959683609356587, 2010.

Klein Goldewijk, K., Beusen, A., Van Drecht, G., and De Vos, M.: The HYDE 3.1 spatially explicit database of human-induced global land-use change over the past 12,000 years, Global Ecol. Biogeogr., 20, 73-86, https://doi.org/10.1111/j.14668238.2010.00587.x, 2011.

Knorr, W., Lehsten, V., and Arneth, A.: Determinants and predictability of global wildfire emissions, Atmos. Chem. Phys., 12, 6845-6861, https://doi.org/10.5194/acp-12-6845-2012, 2012.

Knorr, W., Kaminski, T., Arneth, A., and Weber, U.: Impact of human population density on fire frequency at the global scale, Biogeosciences, 11, 1085-1102, https://doi.org/10.5194/bg-111085-2014, 2014.

Knorr, W., Jiang, L., and Arneth, A.: Climate, $\mathrm{CO}_{2}$ and human population impacts on global wildfire emissions, Biogeosciences, 13, 267-282, https://doi.org/10.5194/bg-13-267-2016, 2016.

Kochi, I., Donovan, G. H., Champ, P. A., and Loomis, J. B.: The economic cost of adverse health effects from wildfiresmoke exposure: a review, Int. J. Wildland Fire, 19, 803-817, https://doi.org/10.1071/WF09077, 2010.

Krawchuk, M. A. and Moritz, M. A.: Constraints on global fire activity vary across a resource gradient, Ecology, 92, 121-132, https://doi.org/10.1890/09-1843.1, 2011.

Krinner, G., Viovy, N., de Noblet-Ducoudré, N., Ogée, J., Polcher, J., Friedlingstein, P., Ciais, P., Sitch, S., and Prentice, I. C.: A dynamic global vegetation model for studies of the coupled atmosphere-biosphere system, Global Biogeochem. Cy., 19, 133, https://doi.org/10.1029/2003GB002199, 2005.

Krol, M., Peters, W., Hooghiemstra, P., George, M., Clerbaux, C., Hurtmans, D., McInerney, D., Sedano, F., Bergamaschi, P., El Hajj, M., Kaiser, J. W., Fisher, D., Yershov, V., and Muller, J.-P.: How much CO was emitted by the 2010 fires around Moscow?, Atmos. Chem. Phys., 13, 4737-4747, https://doi.org/10.5194/acp-13-4737-2013, 2013.

Lamarque, J.-F., Bond, T. C., Eyring, V., Granier, C., Heil, A., Klimont, Z., Lee, D., Liousse, C., Mieville, A., Owen, B., Schultz, M. G., Shindell, D., Smith, S. J., Stehfest, E., Van Aardenne, J., Cooper, O. R., Kainuma, M., Mahowald, N., McConnell, J. R., Naik, V., Riahi, K., and van Vuuren, D. P.: Historical (1850-2000) gridded anthropogenic and biomass burning emissions of reactive gases and aerosols: methodology and application, Atmos. Chem. Phys., 10, 7017-7039, https://doi.org/10.5194/acp-10-7017-2010, 2010.

Lasslop, G., Thonicke, K., and Kloster, S.: SPITFIRE within the MPI Earth system model: Model development and evaluation, J. Adv. Model. Earth Syst., 6, 740-755, https://doi.org/10.1002/2013MS000284, 2014.

Laurance, W. F., Cochrane, M. A., Bergen, S., Fearnside, P. M., Delamônica, P., Barber, C., D'Angelo, S., and Fernandes, T.: The Future of the Brazilian Amazon, Science, 291, 438-439, https://doi.org/10.1126/science.291.5503.438, 2001.

Legrand, M., McConnell, J., Fischer, H., Wolff, E. W., Preunkert, S., Arienzo, M., Chellman, N., Leuenberger, D., Maselli, O., Place, P., Sigl, M., Schüpbach, S., and Flannigan, M.: Boreal fire records in Northern Hemisphere ice cores: a review, Clim. Past, 12, 2033-2059, https://doi.org/10.5194/cp-12-2033-2016, 2016.

Lehsten, V., Tansey, K., Balzter, H., Thonicke, K., Spessa, A., Weber, U., Smith, B., and Arneth, A.: Estimating carbon emissions from African wildfires, Biogeosciences, 6, 349-360, https://doi.org/10.5194/bg-6-349-2009, 2009.

Lenihan, J. M., Daly, C., Bachelet, D., and Neilson, R. P.: Simulating Broad-Scale Fire Severity in a Dynamic Global Vegetation Model, Northwest Sci., 72, 91-103, 1998.

Le Page, Y., Oom, D., Silva, J. M. N., Jönsson, P., and Pereira, J. M. C.: Seasonality of vegetation fires as modified by human action: Observing the deviation from eco-climatic fire regimes, Global Ecol. Biogeogr., 19, 575-588, https://doi.org/10.1111/j.14668238.2010.00525.x, 2010.

Li, F., Zeng, X. D., and Levis, S.: A process-based fire parameterization of intermediate complexity in a Dynamic Global Vegetation Model, Biogeosciences, 9, 2761-2780, https://doi.org/10.5194/bg-9-2761-2012, 2012.

Li, F., Levis, S., and Ward, D. S.: Quantifying the role of fire in the Earth system - Part 1: Improved global fire modeling in the Community Earth System Model (CESM1), Biogeosciences, 10, 2293-2314, https://doi.org/10.5194/bg-10-2293-2013, 2013.

Li, F., Bond-Lamberty, B., and Levis, S.: Quantifying the role of fire in the Earth system - Part 2: Impact on the net carbon balance of global terrestrial ecosystems for the 20th century, Biogeosciences, 11, 1345-1360, https://doi.org/10.5194/bg-111345-2014, 2014.

Mangeon, S., Field, R., Fromm, M., McHugh, C., and Voulgarakis, A.: Satellite versus ground-based estimates of burned area: A comparison between MODIS based burned area and fire agency reports over North America in 2007, Anthr. Rev., 3, 76-92, https://doi.org/10.1177/2053019615588790, 2015.

Mangeon, S., Voulgarakis, A., Gilham, R., Harper, A., Sitch, S., and Folberth, G.: INFERNO: a fire and emissions scheme for the UK Met Office's Unified Model, Geosci. Model Dev., 9, 2685-2700, https://doi.org/10.5194/gmd-9-2685-2016, 2016.

Marlon, J. R., Bartlein, P. J., Carcaillet, C., Gavin, D. G., Harrison, S. P., Higuera, P. E., Joos, F., Power, M. J., and Prentice, I. C.: Climate and human influences on global biomass burning over the past two millennia, Nat. Geosci., 1, 697-702, https://doi.org/10.1038/ngeo313, 2008.

Marlon, J. R., Bartlein, P. J., Daniau, A. L., Harrison, S. P., Maezumi, S. Y., Power, M. J., Tinner, W., and Vanniére, B.: Global biomass burning: A synthesis and review of Holocene paleofire records and their controls, Quaternary Sci. Rev., 65, 5-25, https://doi.org/10.1016/j.quascirev.2012.11.029, 2013.

Marlon, J. R., Kelly, R., Daniau, A.-L., Vannière, B., Power, M. J., Bartlein, P., Higuera, P., Blarquez, O., Brewer, S., Brücher, T., Feurdean, A., Romera, G. G., Iglesias, V., Maezumi, S. Y., Magi, B., Courtney Mustaphi, C. J., and Zhihai, T.: Reconstructions of biomass burning from sediment-charcoal records to improve data-model comparisons, Biogeosciences, 13, 3225-3244, https://doi.org/10.5194/bg-13-3225-2016, 2016.

McConnell, J. R., Edwards, R., Kok, G. L., Flanner, M. G., Zender, C. S., Saltzman, E. S., Banta, J. R., Pasteris, D. R., Carter, M. M., and Kahl, J. D. W.: 20th-Century Industrial Black Carbon Emissions Altered Arctic Climate Forcing, Science, 317, 13811384, https://doi.org/10.1126/science.1144856, 2007.

Mieville, A., Granier, C., Liousse, C., Guillaume, B., Mouillot, F., Lamarque, J.-F., Grégoire, J.-M., and Pétron, G.: Emissions of gases and particles from biomass burning during the 20th century using satellite data and an his- 
torical reconstruction, Atmos. Environ., 44, 1469-1477, https://doi.org/10.1016/j.atmosenv.2010.01.011, 2010.

Mollicone, D., Eva, H. D., and Achard, F.: Ecology: Human role in Russian wild fires, Nature, 440, 436-437, https://doi.org/10.1038/440436a, 2006.

Mooney, S. D., Harrison, S. P., Bartlein, P. J., Daniau, A.L., Stevenson, J., Brownlie, K. C., Buckman, S., Cupper, M., Luly, J., Black, M., Colhoun, E., D'Costa, D., Dodson, J., Haberle, S., Hope, G. S., Kershaw, P., Kenyon, C., McKenzie, M., and Williams, N.: Late Quaternary fire regimes of Australasia, Quaternary Sci. Rev., 30, 28-46, https://doi.org/10.1016/j.quascirev.2010.10.010, 2011.

Mouillot, F. and Field, C. B.: Fire history and the global carbon budget: a $1^{\circ} \times 1^{\circ}$ fire history reconstruction for the 20th century, Glob. Change Biol., 11, 398-420, https://doi.org/10.1111/j.13652486.2005.00920.x, 2005.

Nepstad, D. C., Verssimo, A., Alencar, A., Nobre, C., Lima, E., Lefebvre, P., Schlesinger, P., Potter, C., Moutinho, P., Mendoza, E., Cochrane, M., and Brooks, V.: Large-scale impoverishment of Amazonian forests by logging and fire, Nature, 398, 505-508, https://doi.org/10.1038/19066, 1999.

Pechony, O. and Shindell, D. T.: Fire parameterization on a global scale, J. Geophys. Res., 114, D16115, https://doi.org/10.1029/2009JD011927, 2009.

Potter, C. S., Randerson, J. T., Field, C. B., Matson, P. A., Vitousek, P. M., Mooney, H. A., and Klooster, S. A.: Terrestrial ecosystem production: A process model based on global satellite and surface data, Global Biogeochem. Cy., 7, 811-841, https://doi.org/10.1029/93GB02725, 1993.

Power, M. J., Marlon, J., Ortiz, N., Bartlein, P. J., Harrison, S. P., Mayle, F. E., Ballouche, A., Bradshaw, R. H. W., Carcaillet, C., Cordova, C., Mooney, S., Moreno, P. I., Prentice, I. C., Thonicke, K., Tinner, W., Whitlock, C., Zhang, Y., Zhao, Y., Ali, A. A., Anderson, R. S., Beer, R., Behling, H., Briles, C., Brown, K. J., Brunelle, A., Bush, M., Camill, P., Chu, G. Q., Clark, J., Colombaroli, D., Connor, S., Daniau, A.-L., Daniels, M., Dodson, J., Doughty, E., Edwards, M. E., Finsinger, W., Foster, D., Frechette, J., Gaillard, M.-J., Gavin, D. G., Gobet, E., Haberle, S., Hallett, D. J., Higuera, P., Hope, G., Horn, S., Inoue, J., Kaltenrieder, P., Kennedy, L., Kong, Z. C., Larsen, C., Long, C. J., Lynch, J., Lynch, E. A., McGlone, M., Meeks, S., Mensing, S., Meyer, G., Minckley, T., Mohr, J., Nelson, D. M., New, J., Newnham, R., Noti, R., Oswald, W., Pierce, J., Richard, P. J. H., Rowe, C., Sanchez Goñi, M. F., Shuman, B. N., Takahara, H., Toney, J., Turney, C., Urrego-Sanchez, D. H., Umbanhowar, C., Vandergoes, M., Vanniere, B., Vescovi, E., Walsh, M., Wang, X., Williams, N., Wilmshurst, J., and Zhang, J. H.: Changes in fire regimes since the Last Glacial Maximum: an assessment based on a global synthesis and analysis of charcoal data, Clim. Dynam., 30, 887-907, https://doi.org/10.1007/s00382-007-0334-x, 2008.

Power, M. J., Marlon, J. R., Bartlein, P. J., and Harrison, S. P.: Fire history and the Global Charcoal Database: A new tool for hypothesis testing and data exploration, Palaeogeogr. Palaeocl., 291, 52-59, https://doi.org/10.1016/j.palaeo.2009.09.014, 2010.

Power, M., Mayle, F., Bartlein, P., Marlon, J., Anderson, R., Behling, H., Brown, K., Carcaillet, C., Colombaroli, D., Gavin, D., Hallett, D., Horn, S., Kennedy, L., Lane, C., Long, C., Moreno, P., Paitre, C., Robinson, G., Taylor, Z., and Walsh, M.: Climatic control of the biomass-burning decline in the Americas after AD 1500, Holocene, 23, 3-13, https://doi.org/10.1177/0959683612450196, 2013.

Rabin, S. S., Magi, B. I., Shevliakova, E., and Pacala, S. W.: Quantifying regional, time-varying effects of cropland and pasture on vegetation fire, Biogeosciences, 12, 6591-6604, https://doi.org/10.5194/bg-12-6591-2015, 2015.

Rabin, S. S., Melton, J. R., Lasslop, G., Bachelet, D., Forrest, M., Hantson, S., Kaplan, J. O., Li, F., Mangeon, S., Ward, D. S., Yue, C., Arora, V. K., Hickler, T., Kloster, S., Knorr, W., Nieradzik, L., Spessa, A., Folberth, G. A., Sheehan, T., Voulgarakis, A., Kelley, D. I., Prentice, I. C., Sitch, S., Harrison, S., and Arneth, A.: The Fire Modeling Intercomparison Project (FireMIP), phase 1: experimental and analytical protocols with detailed model descriptions, Geosci. Model Dev., 10, 11751197, https://doi.org/10.5194/gmd-10-1175-2017, 2017.

Randerson, J. T., Chen, Y., van der Werf, G. R., Rogers, B. M., and Morton, D. C.: Global burned area and biomass burning emissions from small fires, J. Geophys. Res., 117, G04012, https://doi.org/10.1029/2012JG002128, 2012.

Reick, C. H., Raddatz, T., Brovkin, V., and Gayler, V.: Representation of natural and anthropogenic land cover change in MPI-ESM, J. Adv. Model. Earth Syst., 5, 459-482, https://doi.org/10.1002/jame.20022, 2013.

Schultz, M. G., Heil, A., Hoelzemann, J. J., Spessa, A., Thonicke, K., Goldammer, J. G., Held, A. C., Pereira, J. M. C., and van het Bolscher, M.: Global wildland fire emissions from 1960 to 2000, Global Biogeochem. Cy., 22, GB2002, https://doi.org/10.1029/2007GB003031, 2008.

Smith, B., Prentice, I. C., and Sykes, M. T.: Representation of vegetation dynamics in the modelling of terrestrial ecosystems: Comparing two contrasting approaches within European climate space, Global Ecol. Biogeogr., 10, 621-637, https://doi.org/10.1046/j.1466-822X.2001.00256.x, 2001.

Stocks, B. J., Mason, J. A., Todd, J. B., Bosch, E. M., Wotton, B. M., Amiro, B. D., Flannigan, M. D., Hirsch, K. G., Logan, K. A., Martell, D. L., and Skinner, W. R.: Large forest fires in Canada, 1959-1997, J. Geophys. Res., 108, 8149, https://doi.org/10.1029/2001JD000484, 2002.

Thonicke, K., Spessa, A., Prentice, I. C., Harrison, S. P., Dong, L., and Carmona-Moreno, C.: The influence of vegetation, fire spread and fire behaviour on biomass burning and trace gas emissions: results from a process-based model, Biogeosciences, 7, 1991-2011, https://doi.org/10.5194/bg-7-1991-2010, 2010.

Tierney, J. E., Mayes, M. T., Meyer, N., Johnson, C., Swarzenski, P. W., Cohen, A. S., and Russell, J. M.: Late-twentieth-century warming in Lake Tanganyika unprecedented since AD 500, Nat. Geosci., 3, 422-425, https://doi.org/10.1038/ngeo865, 2010.

van der Werf, G. R., Peters, W., van Leeuwen, T. T., and Giglio, L.: What could have caused pre-industrial biomass burning emissions to exceed current rates?, Clim. Past, 9, 289-306, https://doi.org/10.5194/cp-9-289-2013, 2013.

van der Werf, G. R., Randerson, J. T., Giglio, L., Collatz, G. J., Kasibhatla, P. S., and Arellano Jr., A. F.: Interannual variability in global biomass burning emissions from 1997 to 2004, Atmos. Chem. Phys., 6, 3423-3441, https://doi.org/10.5194/acp-6-34232006, 2006.

van der Werf, G. R., Randerson, J. T., Giglio, L., Collatz, G. J., Mu, M., Kasibhatla, P. S., Morton, D. C., DeFries, R. S., 
Jin, Y., and van Leeuwen, T. T.: Global fire emissions and the contribution of deforestation, savanna, forest, agricultural, and peat fires (1997-2009), Atmos. Chem. Phys., 10, 11707-11735, https://doi.org/10.5194/acp-10-11707-2010, 2010.

van der Werf, G. R., Randerson, J. T., Giglio, L., Gobron, N., and Dolman, A. J.: Climate controls on the variability of fires in the tropics and subtropics, Global Biogeochem. Cy., 22, GB3028, https://doi.org/10.1029/2007GB003122, 2008.

van der Werf, G. R., Randerson, J. T., Giglio, L., van Leeuwen, T. T., Chen, Y., Rogers, B. M., Mu, M., van Marle, M. J. E., Morton, D. C., Collatz, G. J., Yokelson, R. J., and Kasibhatla, P. S.: Global fire emissions estimates during 1997-2015, Earth Syst. Sci. Data Discuss., https://doi.org/10.5194/essd-2016-62, in review, 2017.

van Leeuwen, T. T. and van der Werf, G. R.: Spatial and temporal variability in the ratio of trace gases emitted from biomass burning, Atmos. Chem. Phys., 11, 3611-3629, https://doi.org/10.5194/acp-11-3611-2011, 2011.

van Leeuwen, T. T., van der Werf, G. R., Hoffmann, A. A., Detmers, R. G., Rücker, G., French, N. H. F., Archibald, S., Carvalho Jr., J. A., Cook, G. D., de Groot, W. J., Hély, C., Kasischke, E. S., Kloster, S., McCarty, J. L., Pettinari, M. L., Savadogo, P., Alvarado, E. C., Boschetti, L., Manuri, S., Meyer, C. P., Siegert, F., Trollope, L. A., and Trollope, W. S. W.: Biomass burning fuel consumption rates: a field measurement database, Biogeosciences, 11, 7305-7329, https://doi.org/10.5194/bg-117305-2014, 2014.

van Marle, M. J. E., Kloster, S., Magi, B. I., Marlon, J. R., Daniau, A.-L., Field, R. D., Arneth, A., Forrest, M., Hantson, S., Kehrwald, N. M., Knorr, W., Lasslop, G., Li, F., Mangeon, S., Yue, C., Kaiser, J. W., and van der Werf, G. R.: Biomass Burning emissions for CMIP6 (v1.2), Version 20161213, Earth System Grid Federation, https://doi.org/10.22033/ESGF/input4MIPs.1117, 2016.

van Marle, M. J. E., Field, R. D., van der Werf, G. R., Estrada de Wagt, I. A., Houghton, R. A., Rizzo, L. V., Artaxo, P., and Tsigaridis, K.: Fire and deforestation dynamics in Amazonia (1973-2014), Global Biogeochem. Cy., 31, 24-38, https://doi.org/10.1002/2016GB005445, 2017.

Venevsky, S., Thonicke, K., Sitch, S., and Cramer, W.: Simulating fire regimes in human-dominated ecosystems: Iberian Peninsula case study, Glob. Change Biol., 8, 984-998, https://doi.org/10.1046/j.1365-2486.2002.00528.x, 2002.
Veraverbeke, S., Rogers, B. M., and Randerson, J. T.: Daily burned area and carbon emissions from boreal fires in Alaska, Biogeosciences, 12, 3579-3601, https://doi.org/10.5194/bg-12-35792015, 2015.

Wang, Z., Chappellaz, J., Martinerie, P., Park, K., Petrenko, V., Witrant, E., Emmons, L. K., Blunier, T., Brenninkmeijer, C. A. M., and Mak, J. E.: The isotopic record of Northern Hemisphere atmospheric carbon monoxide since 1950: implications for the CO budget, Atmos. Chem. Phys., 12, 4365-4377, https://doi.org/10.5194/acp-12-4365-2012, 2012.

Wang, Z., Chappellaz, J., Park, K. and Mak, J. E.: Large variations in Southern Hemisphere biomass burning during the last 650 years, Science, 330, 1663-1666, https://doi.org/10.1126/science.1197257, 2010.

Weedon, G. P., Gomes, S., Viterbo, P., Shuttleworth, W. J., Blyth, E., Österle, H., Adam, J. C., Bellouin, N., Boucher, O., and Best, M.: Creation of the WATCH Forcing Data and Its Use to Assess Global and Regional Reference Crop Evaporation over Land during the Twentieth Century, J. Hydrometeorol., 12, 823-848, https://doi.org/10.1175/2011JHM1369.1, 2011.

Yue, C., Ciais, P., Cadule, P., Thonicke, K., Archibald, S., Poulter, B., Hao, W. M., Hantson, S., Mouillot, F., Friedlingstein, P., Maignan, F., and Viovy, N.: Modelling the role of fires in the terrestrial carbon balance by incorporating SPITFIRE into the global vegetation model ORCHIDEE - Part 1: simulating historical global burned area and fire regimes, Geosci. Model Dev., 7, 2747-2767, https://doi.org/10.5194/gmd-7-2747-2014, 2014.

Yue, C., Ciais, P., Cadule, P., Thonicke, K., and van Leeuwen, T. T.: Modelling the role of fires in the terrestrial carbon balance by incorporating SPITFIRE into the global vegetation model ORCHIDEE - Part 2: Carbon emissions and the role of fires in the global carbon balance, Geosci. Model Dev., 8, 1321-1338, https://doi.org/10.5194/gmd-8-1321-2015, 2015.

Zennaro, P., Kehrwald, N., McConnell, J. R., Schüpbach, S., Maselli, O. J., Marlon, J., Vallelonga, P., Leuenberger, D., Zangrando, R., Spolaor, A., Borrotti, M., Barbaro, E., Gambaro, A., and Barbante, C.: Fire in ice: two millennia of boreal forest fire history from the Greenland NEEM ice core, Clim. Past, 10, 1905-1924, https://doi.org/10.5194/cp-10-1905-2014, 2014. 